\title{
FORMAÇÃO E TRABALHO DE MESTRES E DOUTORES EM BIOQUÍMICA TITULADOS NO BRASIL"
}

\author{
Mauro Mendes Braga* \\ Departamento de Química, Instituto de Ciências Exatas, Universidade Federal de Minas Gerais, CP 702, 31270-901 Belo Horizonte - MG \\ Sérgio de Azevedo \\ Universidade Estadual do Norte Fluminense, Avenida Alberto Lamego, 2000, 28015-620 Campos - RJ
}

Recebido em $2 / 7 / 02$

\begin{abstract}
MASTER AND DOCTORS OF BIOCHEMISTRY FROM BRAZILIAN UNIVERSITIES: TRAINING AND JOBS. This article reports questions related to the training and jobs of biochemistry graduates from Brazilian universities. It is focussed on academic and career paths and on relations between knowledge and work. The main questions addressed in this study were: what have been the paths since undergraduate education? What were graduates doing before their enrolment in master and doctoral programs? Which were their motivations for this? Where do graduates work now? How do they appraise some aspects of their graduate education? Did the degree enlarge their job opportunities and improve work quality? How much do they earn?
\end{abstract}

Keywords: biochemistry graduates; evaluation; training and jobs.

\section{INTRODUÇÃO}

A literatura brasileira registra raros trabalhos abordando a evolução tanto da Biologia como da Bioquímica no país ${ }^{1}$. Além de dois estudos elaborados por Prado ${ }^{2,3}$ — que forneceram alguns elementos adicionais, para se acompanhar a evolução da Bioquímica no Brasil anteriormente a 1965 — os dados estatísticos divulgados pela $\mathrm{CAPES}^{4}$ foram as fontes de maior utilidade para se traçar uma panorâmica do desenvolvimento dos cursos de pós-graduação dessa área no país, a partir dos anos 60 .

Martins ${ }^{5}$ afirma que, no Brasil, anteriormente ao século XX, os únicos trabalhos científicos em Biologia dignos de menção foram os desenvolvidos pelo naturalista Fritz Muller e pelo fisiologista João Batista de Lacerda.

Fritz Muller, que realizou o curso secundário na Universidade de Berlim e doutorou-se aos 22 anos na Universidade de Greifswal ${ }^{6}$, chegou ao Brasil em 1852, aos 30 anos, tendo se radicado em Santa Catarina, onde viveu mais 45 anos. Manteve, por diversos anos, correspondência regular com Charles Darwin. Ao falecer, no ano de 1897, deixou uma obra constituída por 248 memórias, monografias, artigos de periódicos e livros, nos mais diferentes campos da biologia: botânica, embriologia, evolucionismo, genética e zoologia, entre outros, embora jamais tenha se vinculado a qualquer instituição de ensino superior.

Lacerda, fluminense de Campos, graduou-se em Medicina, em 1870. Sete anos depois ingressou no Museu Nacional, onde desenvolveu atividades de pesquisa e de docência em diversos ramos das ciências: anatomia, antropologia, farmacologia, fisiologia, ofiologia e patologia. Foi Diretor do Museu por diversos anos. Faleceu em 1915, aos 69 anos, tendo deixado uma vasta obra científica.

Avaliação similar é feita por Prado $^{3}$ em relação à área específica de Bioquímica. Segundo este autor, conquanto no período entre 1808 e

\footnotetext{
*e-mail: braga@ufmg.br

\# A CAPES e a UNESCO editaram recentemente o livro A pós-graduação no país: formação e trabalho de mestres e doutores no país, organizado por Jacques Velloso. Este artigo é a adaptação para a Química Nova do cap. 6 deste livro.
}

1928 tenham aparecido no Brasil “ ...escolas ou organizações superiores onde a Bioquímica poderia ter sido cultivada ... somente em 1930 apareceram no país os precursores do desenvolvimento ininterrupto da Bioquímica.'. Entre eles, Prado dá especial destaque para Gilberto Guimarães Villela, no Rio de Janeiro, José Baeta Vianna, em Belo Horizonte, Jayme Arcoverde de Albuquerque Cavalcanti e Paulo Enéas Galvão, em São Paulo, todos eles graduados em cursos médicos. Paulo Galvão teria sido o responsável pelo primeiro trabalho científico brasileiro na área que competiu internacionalmente, tendo sido publicado na Alemanha, em 1934, e despertado interesse generalizado.

A atividade de investigação científica em Bioquímica foi realizada inicialmente em algumas poucas instituições, geralmente localizadas no eixo Rio (Instituto Manguinhos, Instituto de Biofísica da Universidade do Brasil ${ }^{7}$ ) São Paulo (Instituto Butantan, Instituto Biológico, Departamento de Química da USP, Departamento de Química Fisiológica da Faculdade de Medicina da USP) e Belo Horizonte (Faculdade de Medicina da Universidade de Minas Gerais $\left.{ }^{8}\right)$. Há também registros de atividades importantes na Faculdade de Medicina da Universidade do Paraná9. Em algumas dessas instituições, a atividade de pós-graduação começou a florescer. Teses de Doutorado e de Livre Docência ${ }^{2}$ foram defendidas na Faculdade de Medicina da Universidade de Minas Gerais (a partir dos anos 40, orientadas por Baeta Vianna), na Faculdade de Medicina da Universidade do Paraná (sete teses de Doutorado e duas de Livre Docência, nas décadas de 40 e 50) e no Instituto de Biofísica da Universidade do Brasil (um total de 13 teses, entre 1946 e 1959).

Mas, foi no Departamento de Química da USP que a pós-graduação em Bioquímica se instalou com maior vigor, a partir dos anos 40. A criação da Universidade de São Paulo, ocorrida em 1934, é um dos mais importantes marcos do ensino superior brasileiro. Pela primeira vez o país via nascer uma instituição de ensino superior que associava ensino e pesquisa e que se orientava para o progresso da ciência $^{10}$. Para chefiar o departamento de Química da USP, veio da Alemanha, nesse mesmo ano, Heinrich Rheinboldt, professor da Universidade de Bonn, então com 43 anos, experimentado pesquisador, que já havia orientado 35 teses de doutoramento em seu país ${ }^{11}$. Um ano depois, ele traria da mesma Alemanha, para ser seu assistente, Heinrich Hauptmann, doutor pela Universidade de Breslau, que aqui chegou aos 30 anos, seis anos após concluir seu doutorado. 
Esses dois professores trabalharam intensamente em atividades de pesquisa na área de Bioquímica, assim como na orientação de teses de Doutorado e de Livre Docência. Quando o Departamento de Química da USP completou 25 anos, Rheinboldt, que falecera em 1955, havia orientado 15 teses de doutorado e Hauptmann, que faleceria no ano seguinte, $14^{12}$. Ainda que uma parte desses trabalhos não tenha sido especificamente na área de Bioquímica, certamente a maioria deles o foi, considerando o campo predominante da atuação desses cientistas. O número 24 da revista Selecta Chimica apresenta, em suas páginas finais ${ }^{13}$, uma relação nominal de ex-alunos do Departamento de Química da USP, até 1965. Desta relação constam 32 teses de doutorado ${ }^{14} \mathrm{e} 4$, de livre docência. Prado $^{9}$ menciona que 19 delas foram apresentadas por profissionais que desenvolveram atividades regulares de pesquisa científica em Bioquímica.

No final da década de 60, quando a pós-graduação foi oficialmente instituída no país, existiam aqui cinco cursos de pós-graduação em Bioquímica, regularmente organizados, ministrados pelas seguintes universidades federais: de Minas Gerais (mestrado $=\mathrm{M}$ e doutorado $=\mathrm{D}$ ), de Pernambuco (M), do Paraná (M e D), do Rio Grande do Sul (M) e do Rio de Janeiro (M e D). Nos dois primeiros anos da década seguinte, quatro novos cursos foram instituídos oficialmente, sendo por eles responsáveis as seguintes instituições: Escola Paulista de Medicina ${ }^{15}(\mathrm{Me}$ D), Federal do Ceará (M), USP - São Paulo (M e D) e USP - Ribeirão Preto (M e D). Nos anos 80, foram criados mais três cursos na área: Fundação Oswaldo Cruz (M e D), UFRJ - Química Biológica (M e D) e Universidade Estadual de Campinas (inicialmente apenas o mestrado, em 1985, ampliando-se para o doutorado, em 1990). Finalmente, em 1992, o curso da UFRGS instituiu também o doutorado e quatro anos depois foi criado curso de mestrado na Universidade Federal do Rio Grande do Norte, completando-se o panorama atual da pós-graduação em Bioquímica no país.

No ano de 2001, existiam, portanto, treze programas de pós-graduação em Bioquímica no Brasil, sendo que em apenas dois deles, os da UFPE e da UFRGN, não se ministra o doutorado. A maioria deles se concentra em dois estados da Federação - Rio de Janeiro e São Paulo que juntos oferecem sete desses treze programas. Nos demais estados, existe quando muito um programa em cada um deles, não se registrando cursos nas regiões Norte e Centro-Oeste. Essa situação é diversa do que ocorre, por exemplo, nas áreas de Física e Química, nas quais o número de cursos é bem maior, cobrindo todas as regiões do país ${ }^{16}$.

Quando da primeira avaliação bienal da $\mathrm{CAPES}^{2}$, referente aos anos 83/84, os cursos de pós-graduação em Bioquímica do país foram assim classificados: mestrado, quatro cursos A e cinco cursos B; doutorado, quatro cursos A e dois B. Dez anos depois, na avaliação referente ao biênio 94/95, o resultado foi o seguinte: mestrado - oito cursos A, três cursos B e um curso C; doutorado - seis cursos A, quatro cursos B e um curso não avaliado, por haver se instalado recentemente. Na última avaliação, realizada em 1998 e já sob nova sistemática, na qual os programas são avaliados em seu conjunto, em uma escala de 1 a 7 , sendo o conceito 7 correspondente a nível internacional, verificou-se o seguinte quadro: três programas 7 , três programas 6 , três programas 5 , dois programas 4 e um programa 3. Em todo o período de avaliação, portanto, observa-se um alto percentual de cursos com conceito elevado, fato que, associado ao número relativamente pequeno de programas e à sua também restrita disseminação pelo país, pode indicar que o padrão de exigência da área é bem superior à média naciona ${ }^{17}$. Ou seja, grupos que ainda não atingiram determinado estágio de desenvolvimento ou não tomam a iniciativa de criar novos programas ou, se o fazem, não obtém sucesso.

A Tabela 1 apresenta alguns indicadores da evolução dos cursos de pós-graduação em Bioquímica no país no período entre 1987 e 1997. Quando se comparam os extremos do período considerado - o ano de 1997 com a média relativa aos anos de 1987 a 1990 - se observa um notável crescimento da área nesse decênio. O número de
Tabela 1. Evolução de alguns indicadores da pós-graduação em Bioquímica no país; médias anuais. Fonte: CAPES

\begin{tabular}{lrrrrr}
\hline Indicador & \multicolumn{5}{c}{ Período } \\
& $87 / 90$ & $91 / 94$ & 95 & 96 & 97 \\
& & & & & \\
\hline Matrículas no mestrado & 306 & 352 & 468 & 473 & 525 \\
Matrículas no doutorado & 216 & 360 & 466 & 480 & 529 \\
Mestres titulados & 58 & 77 & 98 & 130 & 134 \\
Doutores titulados & 26 & 40 & 81 & 91 & 85 \\
Corpo Docente: & & & & & \\
Doutores Permanentes & 217 & 277 & 292 & 232 & 203 \\
Publicações no país* & 106 & 152 & 157 & 100 & 85 \\
Publicações no exterior* & 264 & 398 & 535 & 818 & 760
\end{tabular}

*Soma de artigos de periódicos, capítulos de livros e trabalhos completos em anais

matrículas aumentou cerca de $70 \%$ no mestrado e mais de $140 \%$ no doutorado, enquanto que o crescimento do número de dissertações e de teses foi, em ambos os casos, cerca de duas vezes maior do que o verificado para o número correspondente de matrículas. A publicação veiculada no exterior quase triplicou. Apenas a publicação no país declinou, mas ainda assim esse fato pode resultar de um comportamento atípico verificado nos anos de 1996 e 1997 ou então ser conseqüência da melhoria de seu nível, passando-se a direcionar para veículos do exterior trabalhos antes divulgados no país. Esse crescimento da área ${ }^{18}$ veio acompanhado de um aumento de eficiência, uma vez que o número de doutores do corpo docente permanente foi, em 1997, menor do que a média dos anos 1987 a 1990.

Em 1997, a CAPES organizou em Brasília uma reunião de consultores internacionais, com o propósito de avaliar o seu programa de avaliação da pós-graduação brasileira, prestes a completar 20 anos. Esse grupo de trabalho de alto nível, constituído por professores de seis diferentes países, apresentou um relatório de trabalho com recomendações relativas a esse programa. Entre essas, encontra-se uma que interessa aqui destacar: a importância de se implementar procedimentos para acompanhar as carreiras dos doutores formados em programas com financiamento da CAPES. De fato, a preocupação em acompanhar o processo de inserção profissional de graduados e pós-graduados, relacionando-o com sua formação, não é uma prática habitual em nosso país.

O propósito da presente pesquisa foi justamente o de começar a preencher essa lacuna, investigando questões relativas à formação e ao trabalho de mestres e doutores em Bioquímica titulados nos anos 90, em alguns dos mais antigos cursos de pós-graduação dessa área ${ }^{19}$. Desejava-se conhecer diversos aspectos relativos a esses profissionais, com a intenção de subsidiar a discussão sobre as políticas de pós-graduação para a área no país, além de fornecer elementos para que os programas possam eventualmente redirecionar sua atuação. Quem são os mestres e doutores em Bioquímica? Quais as motivações que os levaram a procurar a pós-graduação? Como a titulação alterou a sua trajetória profissional? Qual é hoje a sua inserção no mercado de trabalho, quanto ganham e quão satisfeitos estão? Qual a contribuição do curso para a sua atuação profissional? A resposta a essas questões é matizada por fatores regionais? Responder e refletir sobre essas indagações motivaram a elaboração do projeto de pesquisa que resultou no trabalho aqui apresentado.

\section{METODOLOGIA}

O projeto de pesquisa, realizado sob o patrocínio financeiro da CAPES e da UNESCO, incluiu diversas outras áreas do conheci- 
mento, além da Bioquímica, resultando em livro recentemente edita$\mathrm{do}^{20}$. O texto aqui apresentado é uma adaptação do capítulo referente à área de Bioquímica deste livro, adequando-o às normas da revista e fazendo inclusões que permitam ao leitor a sua ampla compreensão, fora do contexto do livro.

A escolha dos programas a serem pesquisados decorreu de diversos fatores. O primeiro passo foi montar uma rede de pesquisadores convenientemente disseminada por todo o país. O apoio da CAPES permitiu que se realizassem reuniões de grupos interessados situados em Belo Horizonte, Brasília, Campos, Porto Alegre, Rio de Janeiro, São Paulo e Salvador. Posteriormente, na segunda etapa da pesquisa, quando se coletaram os dados referentes à área de Bioquímica, foram também agregados pesquisadores de Recife.

Um projeto com o escopo proposto envolve custos relativamente elevados, o que recomendava a construção de uma proposta em formato capaz de torná-la compatível com as possibilidades de financiamento. Mister se fez, portanto, eleger programas situados nas mesmas localidades dos grupos de pesquisadores, ou pelo menos próximos delas. Além disto, como a escolha do período a ser pesquisado recaiu sobre os anos de 1990 a 1998 - período mais recente, o que aumenta as chances de localizar o titulado, e que engloba profissionais atuando no mercado há alguns anos — era indispensável que os programas escolhidos tivessem formado estudantes desde 1990. Finalmente, quando em uma mesma região havia mais de um programa que atendia a ambas às características mencionadas, optou-se por aquele de maior tradição, tendo em vista a impossibilidade financeira de incorporar mais de um programa em uma mesma região do país.

Considerando o exposto, foram escolhidos, na área de Bioquímica, os programas de pós-graduação das seguintes universidades: UFPE, UFMG, UFRJ, USP e UFRGS. No caso do doutorado, foram exclu- ídos da análise os dados referentes à UFPE, uma vez que, como visto, este programa atua apenas no mestrado.

O universo a ser pesquisado constituía-se de 302 doutores e 422 mestres. As informações iniciais necessárias ao projeto foram obtidas nas secretarias dos programas selecionados. As entrevistas foram realizadas por telefone, utilizando-se um questionário padrão, elaborado em conjunto pelo grupo de pesquisadores, com discussões habituais, pela internet, e eventuais, em reuniões. Foram entrevistados $61 \%$ do universo dos mestres e $70 \%$, dos doutores. A sistematização e o processamento dos dados foram realizados pela coordenação do projeto em Brasília ${ }^{21}$, a qual remeteu os bancos de dados construídos ${ }^{22}$ para a análise dos diversos grupos. A análise dos dados foi discutida, também pela internet, e em um seminário, ocorrido em junho de 2001, no Rio de Janeiro, possível de ser realizado graças, mais uma vez, ao apoio da CAPES.

\section{QUEM SÃO OS MESTRES E DOUTORES EM BIOQUÍMICA}

Para melhor compreender as questões relativas à formação e ao trabalho de mestres e doutores em Bioquímica, convém considerar algumas características relevantes dos titulados, relativas à sua formação anterior, sexo, tempo até o ingresso na pós-graduação, duração do curso e idade de titulação, de forma a traçar um perfil dos entrevistados nessa pesquisa.

\section{Origem acadêmica e sexo}

Mestres e doutores em Bioquímica ${ }^{23}$, como mostra a Tabela 2, graduaram-se predominantemente em cursos de Biologia, mas com significativa proporção de graduados em áreas conexas, sobretudo

Tabela 2. Área da graduação e da pós-graduação e sexo por universidade, percentuais

\begin{tabular}{|c|c|c|c|c|c|c|c|}
\hline & & \multicolumn{5}{|c|}{ Universidade do curso } & \multirow[b]{2}{*}{ Total } \\
\hline & & UFMG & UFPE & UFRGS & UFRJ & USP & \\
\hline \multirow{10}{*}{$\begin{array}{l}\text { a. Mestres } \\
\text { Área na graduação } \\
\text { e na pós }\end{array}$} & & & & & & & \\
\hline & Outra área & 9,8 & 30,8 & 8,1 & 19,3 & & 13,3 \\
\hline & Agronomia & & & & 13,3 & & 4,4 \\
\hline & Biol./C. Biol./Bioc. & 48,8 & 34,6 & 72,6 & 9,6 & 86,1 & 45,6 \\
\hline & Farm./ Farm. \& Bioq. & 26,8 & 7,7 & 4,8 & 19,3 & 2,8 & 13,3 \\
\hline & Química & 2,4 & 19,2 & 1,6 & 36,1 & 8,3 & 16,1 \\
\hline & Medicina & 12,2 & 3,8 & 8,1 & 2,4 & & 5,2 \\
\hline & Odontologia & & & 1,6 & & 2,8 & 0,8 \\
\hline & Veterinária & & 3,8 & 3,2 & & & 1,2 \\
\hline & Total & 100,0 & 100,0 & 100,0 & 100,0 & 100,0 & 100,0 \\
\hline \multirow[t]{3}{*}{ Sexo } & Masculino & 37,5 & 25,9 & 20,6 & 28,3 & 37,8 & 29,0 \\
\hline & Feminino & 62,5 & 74,1 & 79,4 & 71,7 & 62,2 & 71,0 \\
\hline & Total & 100,0 & 100,0 & 100,0 & 100,0 & 100,0 & 100,0 \\
\hline \multirow{9}{*}{$\begin{array}{l}\text { b. Doutores } \\
\text { Área na graduação } \\
\text { e na pós }\end{array}$} & & & & & & & \\
\hline & Outra área & 4,1 & & 6,7 & 22,4 & 4,1 & 8,9 \\
\hline & Agronomia & & & & & 1,4 & 0,5 \\
\hline & Biol./C. Biol./Bioc. & 26,5 & & 50,0 & 36,7 & 59,5 & 44,6 \\
\hline & Farm./ Farm. \& Bioq. & 42,9 & & 16,7 & 20,4 & 25,7 & 27,2 \\
\hline & Química & 16,3 & & 3,3 & 10,2 & 4,1 & 8,4 \\
\hline & Medicina & 10,2 & & 13,3 & 10,2 & 2,7 & 7,9 \\
\hline & Veterinária & & & 10,0 & & 2,7 & 2,5 \\
\hline & Total & 100,0 & & 100,0 & 100,0 & 100,0 & 100,0 \\
\hline \multirow[t]{3}{*}{ Sexo } & Masculino & 44,0 & & 37,9 & 43,1 & 44,6 & 43,1 \\
\hline & Feminino & 56,0 & & 62,1 & 56,9 & 55,4 & 56,9 \\
\hline & Total & 100,0 & & 100,0 & 100,0 & 100,0 & 100,0 \\
\hline
\end{tabular}


Farmácia, Química e Medicina. Esse mosaico apresenta nuanças diferentes de acordo com a instituição formadora, conforme visto nessa mesma tabela. Entre os mestres, na UFRGS e sobretudo na USP, é pouco significativo o número de titulados advindos de áreas conexas. Por outro lado, na UFRJ chama a atenção a pequena fração de mestres graduados em cursos de Biologia, cerca de $10 \%$, enquanto que a soma de químicos e farmacêuticos supera $50 \%{ }^{24}$.

Situação similar é observada no caso dos doutores. Na USP e na UFRGS, é maior a proporção de graduados em cursos de Biologia, enquanto que aqueles formados nas áreas conexas são, na maioria dos casos, farmacêuticos. Na UFRJ, pouco mais de $1 / 3$ dos doutores são oriundos de cursos de Biologia, observando-se uma grande diversidade de formação dos outros $2 / 3$, de tal forma que na categoria "outra área" enquadram-se quase 1/4 dos entrevistados. Na UFMG, ao contrário do observado nas demais universidades pesquisadas, a maior parte dos doutores graduou-se em Farmácia, sendo que, surpreendentemente, a proporção dos biólogos é apenas um pouco maior do que a dos químicos. Verifica-se, portanto, nessa instituição, uma acentuada diferença de comportamento, entre mestres e doutores, no que se refere a esse aspecto: quase a metade dos mestres graduou-se em Biologia; apenas 1/4 dos doutores o fizeram.

Os mestres e os doutores em Bioquímica são predominantemente do sexo feminino (ver ainda a Tabela 2). Para os mestres, essa característica é bastante acentuada em todas as instituições estudadas, ainda que na UFRGS a fração de mulheres se aproxime de $4 / 5$, enquanto que na USP e na UFMG seja pouco maior do que 3/5. Para os doutores, a proporção de mulheres, embora também maior do que a de homens, é menor do que entre os mestres. Esses números sugerem que a área estaria se tornando mais "feminina" nos últimos anos. De fato, entre 1990 e 1996, houve equilíbrio no número de mulheres e de homens titulados no doutorado, mas, para as coortes de 97 e 98, a população foi francamente feminina, chegando a 3/4 dos entrevista$\operatorname{dos}^{25}$. Já no caso dos mestres, a predominância feminina foi verificada desde os anos iniciais do período considerado.

\section{Idade de conclusão da graduação, de ingresso na pós-graduação e tempo entre a conclusão da graduação e o ingresso na pós-graduação}

As Figuras 1a e 1b apresentam as idades médias de conclusão da graduação, de início da pós-graduação e de titulação, dos mestres e doutores em Bioquímica, por ano de titulação, variáveis que serão consideradas nessa e na próxima subseções. A idade média de gra- duação dos doutores, pouco mais de 23 anos, é quase um ano inferior à dos mestres, que supera 24 anos. Ou seja, configura-se uma tendência de aumento da idade média de graduação, tendência essa que aparece de forma nítida no Figura 1a. Quando se agregam os dados referentes a mestres e doutores, o que se observa é que a tendência de aumento progressivo e pronunciado da idade média de graduação cristaliza-se para os graduados a partir de $1985^{26}$, razão pela qual esta não é observada entre os doutores ${ }^{27}$ (Figura 1b).

Não é surpresa o aumento da idade média de graduação. Em meados dos anos 80, os currículos de graduação, em diversas áreas, foram "engordados", como resultado de pelo menos três fatores. O primeiro deles foi a tendência de grupos procurarem ampliar seus espaços nas universidades via aumento de carga horária, o que implicava a necessidade de admissão de mais professores. Era um período em que os controles externos à expansão do corpo docente não eram muito rigorosos. O segundo, foi a ação do Conselho Federal de Educação, que aumentou substancialmente a carga horária mínima de diversos cursos. O terceiro, foi a ação, direta ou indireta, das corporações profissionais, que pressionaram para a inclusão de disciplinas e conteúdos nos projetos curriculares. Resultou daí um aumento médio na duração dos cursos de graduação ${ }^{28}$.

$\mathrm{O}$ ingresso no mestrado ocorre em média 3 anos após o término da graduação, sendo que esse tempo registrou tendência de decréscimo ao longo do período estudado, conforme se verifica na Figura 2. Os valores referentes às coortes de 1990 e 1991 são atípicos, em decorrência de sua pequena população ${ }^{29}$, enquanto que no período 1992-98 esse parâmetro passou de mais de 3 anos para menos de 2 anos e meio, ainda que em um ou outro ano tenha se observado uma reversão dessa tendência. A comparação do valor médio observado para coortes de 1990 a 1995 (3,3 anos) com aquele verificado para as coortes de 1996 a 1998 (2,9 anos) confirma essa tendência, ainda que essa comparação deva ser vista com certa cautela, em razão da diferença de população entre os dois conjuntos de coortes ${ }^{30}$. A diminuição do interregno entre a conclusão da graduação e o início da pós tende a compensar o aumento da idade de graduação, de tal forma que a idade média de ingresso no mestrado não variou muito entre as coortes, sendo de 27 a 28 anos para a maioria delas, como pode ser verificado na Figura 1a.

A média de 3 anos para o interregno entre a graduação e o início do mestrado tem dispersão elevada (desvio padrão superior a 4), caracterizando trajetórias bem diferenciadas. Quase 60\% dos mestres foram admitidos no curso até um ano após se graduarem. Considerando a forma como os intervalos de tempo foram calculados em nossa

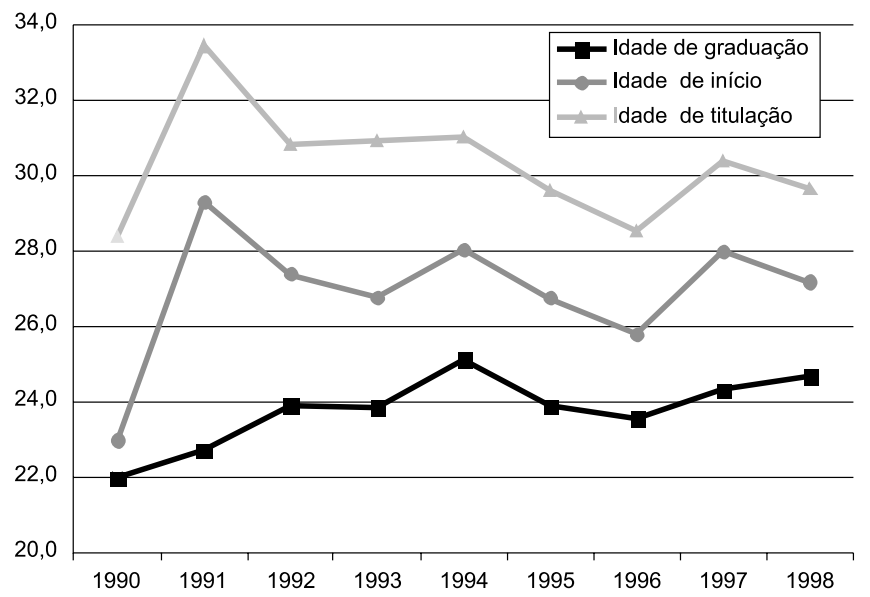

Figura 1a. Idades dos mestres na trajetória da graduação à titulação; médias anuais em anos

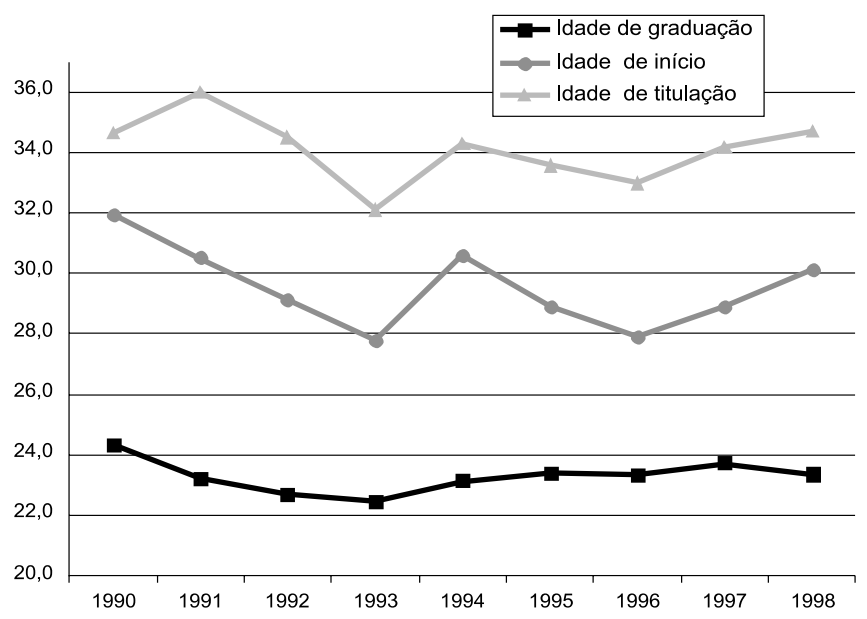

Figura 1b. Idades dos doutores na trajetória da graduação à titulação; médias anuais em anos 
pesquisa $^{31}$, pode-se dizer que boa parte destes o fizeram logo em seguida à conclusão da graduação. Outros $25 \%$ ingressaram no mestrado de dois a cinco anos após a graduação, enquanto que para os $15 \%$ restantes esse tempo é muito variado, chegando a atingir mais de 20 anos.

Os mestres cujos pais têm escolaridade de, no máximo, primeiro grau completo, que representam quase $1 / 3$ do universo de mestres entrevistados, demoram mais para ingressar na pós-graduação, conforme ilustra a Figura 2a. Esse fato talvez possa ser explicado pela necessidade imediata de trabalhar, tão logo a graduação é concluída. Há, entretanto, que observar que mais de $50 \%$ desses mestres ingressaram na pós até um ano após se graduarem (percentual similar ao observado para os mestres filhos de pais com maior nível de instrução). Ou seja, a média de cerca de 4 anos para esse interregno tem dispersão elevada e existe uma alta percentagem destes mestres que procura a pós-graduação tão rapidamente quanto seus demais colegas. Essa mesma tendência — de procura mais tardia, em média, pela pós-graduação - não se observa quando se comparam os mestres filhos de pais com instrução de segundo grau completo com aqueles cujos pais têm diploma de curso superior. Nesse caso, a diferença no interregno entre a conclusão da graduação e o início da pós é bem menor e os filhos de pais com menor nível de instrução são os que se dirigem mais rapidamente para a pós-graduação.

Observa-se uma enorme diferença no tempo entre a conclusão da graduação e o início do mestrado, quando se comparam os mestres que tiveram bolsa de estudos com os que não tiveram: os primeiros ingressaram no curso antes que tenham transcorrido, em média, 3 anos da graduação, os últimos somente 10 anos após se gradua-

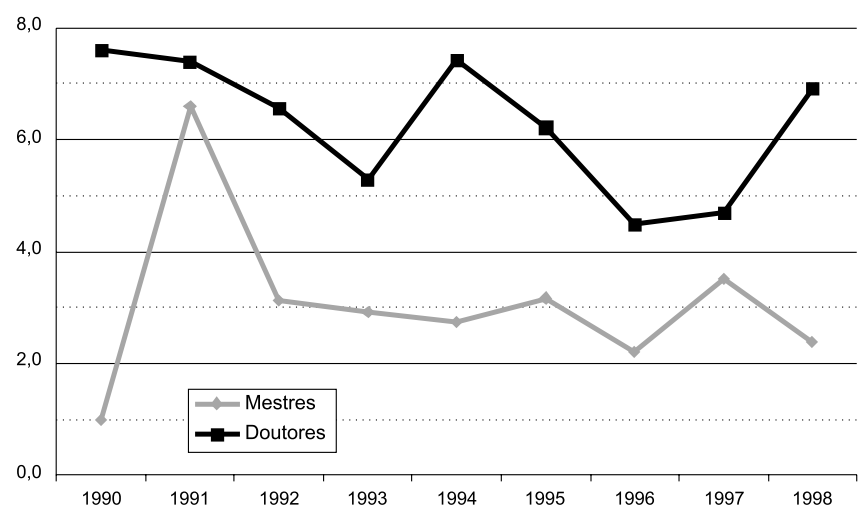

Figura 2. Tempo, em anos, entre a graduação e o início do curso; médias por ano de conclusão

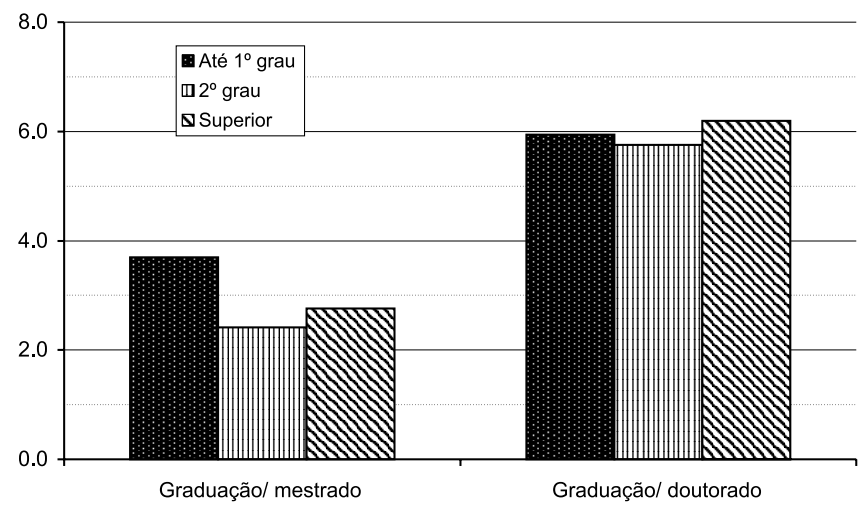

Figura 2a. Tempo entre a graduação e o início do curso, por escolaridade do pai; médias em anos rem. Uma diferença correspondente é obviamente verificada quando se comparam as idades médias de ingresso no mestrado desses dois grupos. O primeiro ingressa no curso, em média, antes de completar 27 anos e o segundo só o faz após os 32 anos. Convém mencionar, no entanto, que menos de $10 \%$ dos mestres entrevistados não tiveram acesso a bolsa de estudos durante o curso. Portanto, esta diferença muito provavelmente não decorre do fator bolsa, mas sim de uma opção profissional diferenciada, por parte daqueles que não tiveram bolsa de estudo.

O ingresso no doutorado ocorre em média 6 anos após o término da graduação e conquanto se observem grandes oscilações nessa variável, de coorte para coorte (ver Figura 2), configura-se uma tendência de diminuição desse interregno. Essa tendência torna-se nítida quando se comparam as coortes de 1990 a 1994 com as de 1995 a $1998^{32}$. No primeiro caso, o tempo médio observado foi de 6,4 anos e no segundo, de 5,8 anos, uma diferença de cerca de 10\%. Essa tendência, no período entre 1990 e 1993, refletiu-se na diminuição da idade média de ingresso no doutorado - cujo valor para o conjunto das coortes estudadas foi de 29,2 anos - conforme pode ser verificado na Figura 1b. A partir de 1993, no entanto, essa idade variou de forma irregular, refletindo diversos fatores: a idade de graduação, a duração do mestrado, o interregno entre o mestrado e o doutorado e a existência na área de Bioquímica de um contingente apreciável de doutores, cerca de $25 \%$ (mas este percentual varia conforme a coorte), que foram direto da graduação para o doutorado. Para a maioria das coortes, a idade média de ingresso no doutorado ficou entre 29 e 30 anos, bastante elevada para padrões internacionais, uma vez que a idade média de doutoramento em cursos da área biológica é da ordem de 28 anos, tanto na Europa ocidental, como nos Estados Unidos ${ }^{33}$.

Com relação aos aspectos mencionados no parágrafo anterior, há que se diferenciar dois grupos distintos. Aqueles que concluíram o mestrado anteriormente ao doutorado e os que foram direto para o doutorado, queimando a etapa do mestrado. Os primeiros ingressaram no doutorado em média 7 anos após a graduação. No entanto, muitos deles o fizeram praticamente em seguida à conclusão do mestrado: quase $2 / 3$ ingressaram no doutorado no máximo um ano após a conclusão do mestrado ${ }^{34} \mathrm{e}$ o tempo médio entre os dois eventos é de pouco mais de 2 anos. Já no segundo caso, o ingresso no doutorado ocorre cerca de 3 anos após a conclusão da graduação. Metade deles no período de até dois anos após se graduarem e apenas $15 \%$ com 5 ou mais anos de graduados. Ou seja, a admissão direta ao doutorado parece estar ocorrendo preferencialmente nos casos de estudantes que apresentam desempenho destacado na graduação e apenas secundariamente para atender ao interesse de profissionais cuja experiência profissional pudesse compensar a ausência da formação do mestrado. Em consequiência dessas trajetórias diversas, o grupo que foi direto da graduação para o doutorado ingressou no curso, em média, antes de completar 27 anos, enquanto que os que passaram pela etapa do mestrado só o fizeram após os 30 anos, em média.

Quando o tempo decorrido entre a conclusão da graduação e o ingresso no doutorado é analisado considerando-se a escolaridade dos pais dos titulados (ver Figura 2a), não se observa correlação entre essas duas variáveis: o tempo médio observado foi de cerca de 6 anos, para todas as categorias de escolaridade consideradas. O mesmo vale para a idade média de ingresso no doutorado, que é cerca de 29 anos, para todas essas categorias de escolaridade. Tendo em vista o que foi discutido em relação a esses aspectos para os mestres e considerando também outros dados que serão apresentados na seqüência desse trabalho, parece configurar-se um quadro em que as influências do capital cultural no desempenho dos indivíduos tendem a diminuir consideravelmente, à medida que o nível de instrução aumenta. Sampaio e 
colaboradores apresentam dados referentes ao exame nacional de cursos (provão) que corroboram essa hipótese ${ }^{35}$.

Convém ainda mencionar, em relação aos aspectos considerados nesta subseção, o elevado percentual de mestres e doutores cujos pais, no máximo, concluíram apenas o primeiro grau. Estes correspondem a quase $1 / 3$ dos mestres e a $40 \%$ dos doutores. Vê-se portanto que, pelo menos entre aqueles que procuram a pós-graduação na área de Bioquímica, não se confirma a hipótese, freqüentemente veiculada, de que o ensino superior brasileiro, sobretudo no segmento público, estaria formando apenas os filhos das classes sociais mais favorecidas. Considerando-se que todos os cursos pesquisados são de universidades públicas, situados entre os melhores do país na área, é razoável supor que boa parte de seus titulados também graduaram-se em instituições estatais. Ademais, os entrevistados devem ter sido, em média, do grupo de estudantes de melhor desempenho na graduação, quando comparado a seus colegas que não se dirigiram para a pós-graduação ${ }^{36}$. Sendo assim, é possível que, entre aqueles graduados que não se dirigiram para a pós-graduação, a proporção de indivíduos oriundos de estratos sociais menos favorecidos seja pelo menos igual à verificada entre os entrevistados. Essas observações sugerem que nas instituições públicas, em especial em seus cursos de Biologia e Farmácia (os que mais fornecem alunos para a pós-graduação em Bioquímica), gradua-se expressiva proporção de jovens pertencentes aos estratos inferiores da classe média.

Em relação à época de conclusão da graduação, os estudantes que não tiveram bolsa durante o curso demoraram 14 anos para chegar ao doutorado, enquanto os bolsistas o fizeram em 5 anos. Da mesma forma, os ex-bolsistas ingressam no doutorado bem mais jovens antes de completarem 29 anos - do que os não bolsistas, que só o fazem após os 35 anos. Repete-se aqui a situação observada no caso dos mestres. Cerca de $90 \%$ dos entrevistados foram bolsistas. Portanto, o ingresso tardio no doutorado, certamente, não se deve à falta da bolsa, mas sim a uma opção profissional, quando do término da graduação ou do mestrado. Reforça essa hipótese o fato de que aqueles poucos que não tiveram bolsa encontravam-se, em sua grande maioria (cerca de $80 \%$ ), em plena atividade quando se inscreveram no doutorado.

\section{Duração do curso e idade de titulação}

A duração média do mestrado em Bioquímica é de quase 3 anos. Esse prazo apresentou nítida e progressiva tendência de queda no período estudado, conforme podemos observar na Figura 3: no início da década, aproximava-se de cinco anos, enquanto que se reduziu, nos últimos anos estudados, para pouco mais de dois anos e meio ${ }^{37}$. Provavelmente este fato é uma conseqüência direta de políticas que vêm sendo adotadas pelas agências de fomento, especialmente

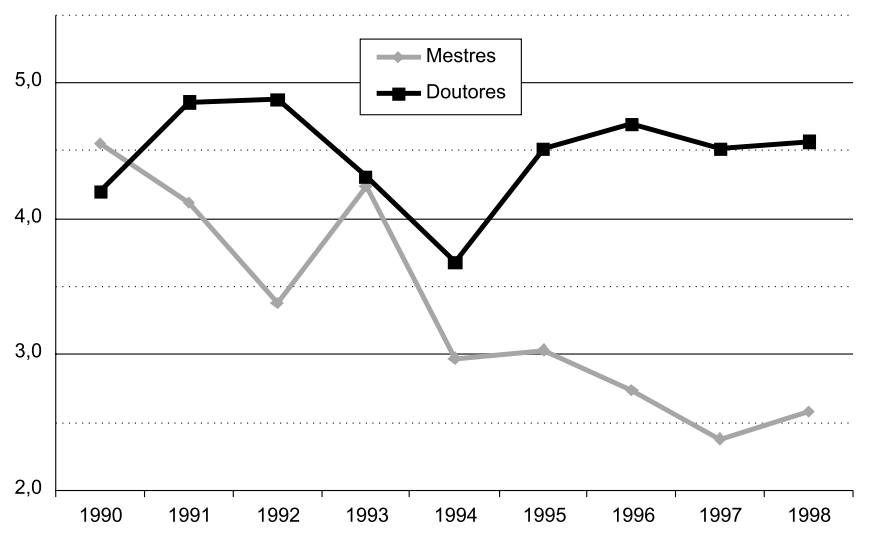

Figura 3. Duração do curso em anos, médias por ano de conclusão a CAPES, voltadas para a melhoria da produtividade dos cursos de pós-graduação stricto sensu, o que inclui a diminuição do prazo para titulação. $\mathrm{Na}$ área de Bioquímica os resultados dessas políticas parecem muito expressivos.

A duração do mestrado é marcadamente influenciada pela instituição formadora. Na UFMG e na UFRJ, o tempo médio é menor, cerca de 2,5 anos, crescendo na USP e na UFRGS para valores próximos à média global, e alcançando quase 4 anos na UFPE. Por outro lado, essa média é praticamente independente do sexo dos entrevistados.

Observa-se uma diferença de cerca de 0,7 anos, quando se compara a duração média do mestrado de bolsistas e não bolsistas. Os primeiros concluem o mestrado em menos tempo. Esse resultado corresponde a cerca de 1/4 do tempo médio de duração do mestrado. Entretanto, parece prematuro creditar essa diferença ao fator bolsa, sem resultados adicionais que confirmem essa hipótese. Há que se considerar que a coorte dos não bolsistas é muito pequena, correspondendo a menos de $10 \%$ dos mestres entrevistados. Além disso, os não bolsistas se dirigiram para o mestrado em média dez anos após se graduarem, enquanto que os bolsistas o fizeram bem mais precocemente, como já visto. Esse fato, à primeira vista, sugeriria, até mesmo, uma dificuldade bem maior, para acompanhar o curso, dos que não tiveram bolsas, quando comparados aos bolsistas. Possivelmente essa dificuldade estaria sendo compensada, ao menos parcialmente, pelo fato de quase todos os mestres não bolsistas estarem empregados quando ingressaram no curso, sendo que $2 / 3$ deles eram vinculados profissionalmente ou a instituições de ensino superior ou a institutos de pesquisa, todos eles com razoável experiência profissional, o que lhes permitia desfrutar de condições propícias para se adaptarem ao mestrado.

A duração do mestrado não sofre interferência do grau de instrução do pai do entrevistado, conforme se observa na Figura 3a. É razoável supor, como já mencionado, que a trajetória da graduação para o doutorado tenha eliminado qualquer significado prático que a origem social poderia ter em relação ao desempenho acadêmico dos titulados. No entanto, deve-se reconhecer que são possíveis outras interpretações para explicar a não-interferência do nível de instrução do pai na duração do mestrado ${ }^{38}$.

A duração média do doutorado em Bioquímica foi de quatro anos e meio, valor este que variou de forma irregular e com pequena amplitude ao longo da década, como se observa na Figura 3. Excetuada a coorte de 1994, para a qual a duração do curso foi menor do que quatro anos, para as demais coortes esse valor médio oscilou entre quatro e cinco anos. $\mathrm{O}$ desvio padrão associado a essa variável é relativamente pequeno, o que reflete o fato de que mais da metade dos entrevistados concluíram o curso em 4 anos, enquanto outros $40 \%$ o fizeram em 5 ou 6 anos. A duração do doutorado, a exemplo do que já foi observado no mestrado,

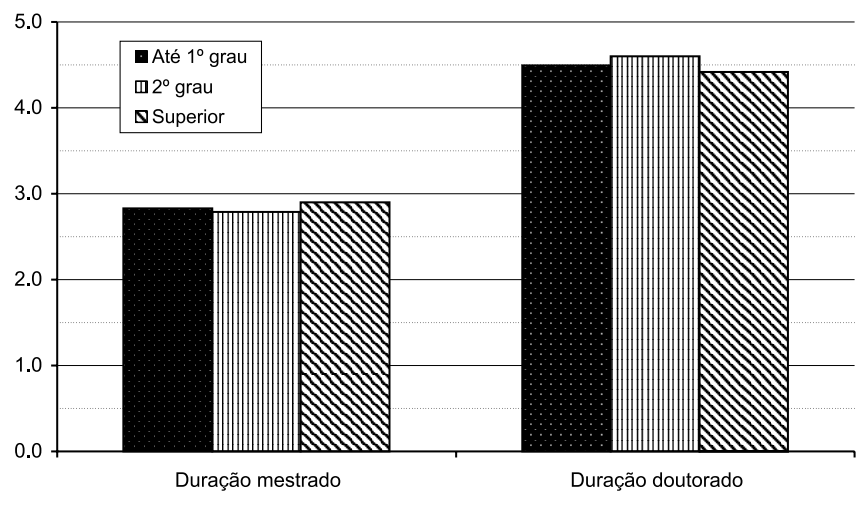

Figura 3a. Duração do curso por escolaridade do pai; média em anos 
não é influenciada pelo nível de instrução dos pais dos entrevistados, conforme se pode verificar na Figura 3 a.

Da mesma forma do que o observado para os mestres, os nãobolsistas levam mais tempo para concluir o curso do que os bolsistas. A diferença, de cerca de 0,6 anos, que corresponde a cerca de $15 \%$ da duração média do curso, é proporcionalmente menos significativa do que no mestrado. Cabem aqui comentários similares aos feitos no caso dos mestres. O universo dos não-bolsistas corresponde a menos de $10 \%$ do total de entrevistados e os não bolsistas dirigiram-se para o doutorado quase 15 anos após se graduarem, enquanto os bolsistas o fizeram, em média, 5 anos depois deste evento. Portanto, é prematuro atribuir-se essa diferença à bolsa, sem outras observações que também apontassem nessa direção. O mais plausível, talvez, seja supor que a diferença de tempo entre a graduação e o ingresso no doutorado tenderia a provocar um desempenho bem pior dos não-bolsistas vis-a-vis os bolsistas. Entretanto, os fatores experiência profissional e maturidade compensariam esse maior tempo afastado dos bancos escolares, levando bolsistas e não-bolsistas a mostrarem um desempenho acadêmico, mensurado pela duração do doutorado, se não igual, pelo menos similar.

Ao contrário do observado no caso do mestrado, a duração do curso é praticamente a mesma em todas as universidades pesquisadas ${ }^{39}$. Cabe ainda mencionar que aqueles que foram direto para o doutorado concluem o curso cerca de seis meses, em média, antes do que seus colegas que são mestres ${ }^{40}$, o que confirma a hipótese feita anteriormente de que esses estudantes teriam desempenho acadêmico diferenciado, em relação aos demais colegas. Tendo em vista os dados apresentados e a ação da CAPES, ao longo desse período, no sentido de otimizar essa variável, é possível imaginar que, na área de Bioquímica, a duração média do doutorado, se ainda não alcançou um valor ideal, está próxima de alcançá-lo.

A idade média de titulação no mestrado é de 30 anos. Quando se comparam as coortes de 1990 a 1994, tomadas no seu conjunto, com as coortes de 1995 a 1998, também no seu todo, verifica-se um significativo decréscimo nessa média: 31,3 anos no primeiro caso e 29,6, no segundo. No entanto, excetuadas as coortes de 1990 e 1991, cujas populações são pequenas quando comparadas às demais ${ }^{41}$, essa média, em geral, sofreu variações pouco expressivas com o ano de conclusão, conforme ilustrado pela Figura 1a. Ou seja, no período posterior a 1991, a tendência de diminuição do interregno entre a graduação e o início do mestrado e a maior eficiência no prazo de conclusão do mestrado foram compensadas, quase que completamente, pelo aumento da idade média de graduação.

Há diferenças expressivas na idade média de conclusão do mestrado, conforme a instituição formadora, variando de 28 anos, na USP, até 32 anos, na UFPE ${ }^{42}$. Essas diferenças podem ser percebidas na Tabela 3 , que apresenta faixas etárias referentes à idade de titulação. Por exemplo, enquanto na USP 4/5 dos mestres titularamse até 30 anos, na UFPE menos da metade dos mestres pertenciam, ao titular-se, a esse grupo etário. Para o conjunto das instituições pesquisadas, verificou-se que $2 / 3$ dos mestres concluem o curso até 30 anos e outros $20 \%$ o fazem na faixa de 31 a 35 anos.

Os doutores titularam-se em média aos 34 anos de idade, bem mais velhos do que seus colegas dos EUA e da Itália ${ }^{43}$ que se doutoram com cerca de 28 anos $^{33}$. Essa média, que se aproximava dos 35 anos em 1990, decresceu para menos de 33 anos em 1993, voltando a mostrar tendência de crescimento a partir desse ano, de tal forma que o valor registrado em 1998 foi exatamente o mesmo do início da década, conforme pode ser verificado na Figura 1b. Quando se considera cada uma das instituições formadoras em separado, verificase que na USP a média é de 32,5 anos, enquanto que na UFMG, na UFRGS e na UFRJ se aproxima de 35 anos, com pequenas variações entre elas. Essas características se refletem na Tabela 3, que apresenta
Tabela 3. Idade de titulação em grupos etários por universidade, percentuais

\begin{tabular}{lrrrrrr}
\hline & \multicolumn{7}{c}{ Universidade do curso } & \\
& UFMG & UFPE UFRGS & UFRJ & USP & Total \\
\hline a. Mestres & & & & & & \\
\hline Até 30 & 67,5 & 44,4 & 57,4 & 75,3 & 80,0 & 66,8 \\
De 31 a 35 & 25,0 & 29,6 & 21,3 & 13,6 & 17,1 & 19,7 \\
De 36 a 40 & 7,5 & 18,5 & 9,8 & 8,6 & 2,9 & 9,0 \\
De 41 a 45 & & 3,7 & 8,2 & 2,5 & & 3,3 \\
46 e mais & & 3,7 & 3,3 & & & 1,2 \\
\hline Total & 100,0 & 100,0 & 100,0 & 100,0 & 100,0 & 100,0 \\
\hline b. Doutores & & & & & & \\
\hline Até 30 & 20,4 & & 21,4 & 18,2 & 38,9 & 26,5 \\
De 31 a 35 & 40,8 & & 46,4 & 50,9 & 43,1 & 45,1 \\
De 36 a 40 & 22,4 & & 17,9 & 18,2 & 9,7 & 16,2 \\
De 41 a 45 & 12,2 & & 7,1 & & 6,9 & 6,4 \\
46 e mais & 4,1 & & 7,1 & 12,7 & 1,4 & 5,9 \\
\hline Total & 100,0 & & 100,0 & 100,0 & 100,0 & 100,0 \\
\hline
\end{tabular}

a idade de titulação discriminada por faixa etária: na USP a fração dos doutores que se titulam antes dos 30 anos é quase que o dobro da verificada nas demais universidades.

Conquanto a idade média de titulação seja muito elevada, quando comparada aos padrões internacionais, deve-se observar que mais de 1/4 dos doutores titulam-se até 30 anos (ver Tabela 3). Estes, integrados por $60 \%$ dos que foram direto da graduação para o doutorado e $14 \%$ dos demais, titularam-se, em média, aos 28,7 anos, resultado similar aos observados nos EUA e na Itália.

As mulheres titulam-se um pouco mais velhas do que os homens, tanto no mestrado como no doutorado. As diferenças observadas foram de 0,4 anos no mestrado e de 0,6 anos no doutorado. Considerando a faixa etária de titulação, essa diferença pode ser atribuída aos diversos casos de gestação que certamente ocorreram durante o percurso acadêmico das doutorandas.

Quando se agregam as coortes de 1990 a 1994, de um lado, e as de 1995 a 1998, de outro, verifica-se que a idade média de doutoramento é praticamente a mesma, para ambos os grupos. $\mathrm{Ou}$ seja, não se identifica, no caso dos doutores, qualquer tendência de variação nessa média. Além disso, ao consultar o banco de dados dos mestres, observam-se fortes indícios de que ela, na melhor das hipóteses, permanecerá nesse patamar nos próximos anos, pelos motivos que se seguem. Como já mencionado, cerca de 3/4 dos doutores cursaram anteriormente o mestrado e doutoram-se em média aos 35 anos. A fração restante, que vai direto da graduação para o doutorado, titula-se com idade média inferior a 31 anos, ou seja mais de 4 anos mais jovens do que os colegas vindos do mestrado. Como a idade média de conclusão do mestrado é de 30 anos, o interregno entre o mestrado e doutorado é de 2,2 anos e a duração do doutorado, para aqueles que cursaram o mestrado, é de 4,7 anos, conclui-se que esse grupo terá, ao se doutorar, 36,9 anos. Supondo-se que a idade média de titulação dos doutores que vão direto da graduação para o doutorado permaneça inalterada, bem como a proporção destes no total dos doutores, pode-se estimar que a idade média de doutoramento em Bioquímica, para as turmas que concluirão o curso nos próximos anos, será de aproximadamente 35,5 anos. Se nesse cálculo considerarmos apenas os mestres que já se encontram vinculados a programa de doutoramento, cuja idade média de titulação no mestrado foi de 28,5 anos, essa projeção cai para 34,4 anos ${ }^{44}$. 
Quais são os fatores que justificariam essa previsão de manutenção ou de crescimento da idade média de doutoramento? Para responder a essa questão, devemos considerar separadamente os doutores que fizeram anteriormente o mestrado e compará-los com os mestres. Quando essa confrontação é feita, observa-se que esses doutores graduaram-se cerca de um ano mais jovens do que os mestres, mesmo quando são considerados apenas os mestres que já estão vinculados a programa de doutoramento. Além disso, é possível, com os dados colhidos, projetar que os atuais mestres gastarão cerca de 8 anos, para cumprir a trajetória da graduação até o ingresso no doutorado, trajetória essa que foi cumprida pelos doutores em um tempo médio da ordem de 7 anos. Essa diferença de um ano será, praticamente toda ela, devida à diferença de tempo observada no percurso entre a graduação e o início do mestrado. Ou seja, mesmo que os mestres estejam procurando o mestrado cada vez mais próximo do momento em que concluíram a graduação, eles o estão fazendo em um tempo médio que ainda é superior ao que foi registrado pelos doutores.

Considerando que os doutores em Bioquímica, em sua quase totalidade, irão atuar na área acadêmica e que nessa área cada vez mais o doutorado é condição de ingresso, o início tão tardio da atividade profissional, ocasionado pela elevada idade de titulação, talvez possa ser um fato a merecer a atenção das autoridades da área. É possível que seja conveniente a adoção de mecanismos indutores específicos, para evitar que a idade média de conclusão do doutorado exceda limites razoáveis. Um desses mecanismos, como demonstrado nos parágrafos anteriores, seria o de incentivar a alternativa do doutorado direto, prescindindo da etapa prévia do mestrado. Essa via parece ter sido usada até aqui apenas por estudantes de desempenho acadêmico diferenciado. No entanto, é possível que essa trajetória possa ser percorrida também com sucesso por todos aqueles que, ao concluírem a graduação, já demonstrarem uma nítida inclinação para seguir carreira acadêmica.

\section{ESTUDO E TRABALHO DE MESTRES E DOUTORES QUANDO SE INSCREVERAM NA PÓS-GRADUAÇÃO}

As Tabelas 4a e 4b apresentam a situação de estudo e trabalho de mestres e doutores em Bioquímica, à época em que se inscreveram na pós-graduação. Cerca de $30 \%$ dos mestres declararam que, quando da inscrição para o mestrado, cursavam a graduação. Do ponto de vista prático, este percentual é ainda maior, uma vez que mais da metade dos mestres começou o curso até um ano após a conclusão da graduação. Ou seja, tratam-se de graduados cuja primeira opção profissional foi a de prosseguir seus estudos no mestrado, o que fizeram na primeira oportunidade. A proporção dos que ainda eram estudantes de graduação quando foram admitidos no curso é mais expressiva na UFMG e na UFRJ e menor na UFPE e na UFRGS.

Entre os doutores, mais da metade dos consultados declararam que, quando se inscreveram para o doutorado, eram estudantes. Quase todos eles, de mestrado. Mas observa-se também uma pequena parcela que declarou ter se inscrito para o doutorado ainda quando alunos de graduação. É provável que esses doutores tenham se equivocado, uma vez que dificilmente se selecionam alunos recém graduados diretamente para o doutorado. O mais comum é observar-se alunos que, selecionados para o mestrado, apresentam desempenho acadêmico tão destacado que os possibilita, posteriormente, passar direta-

Tabela 4a. Situação de trabalho dos mestres na inscrição por universidade, percentuais

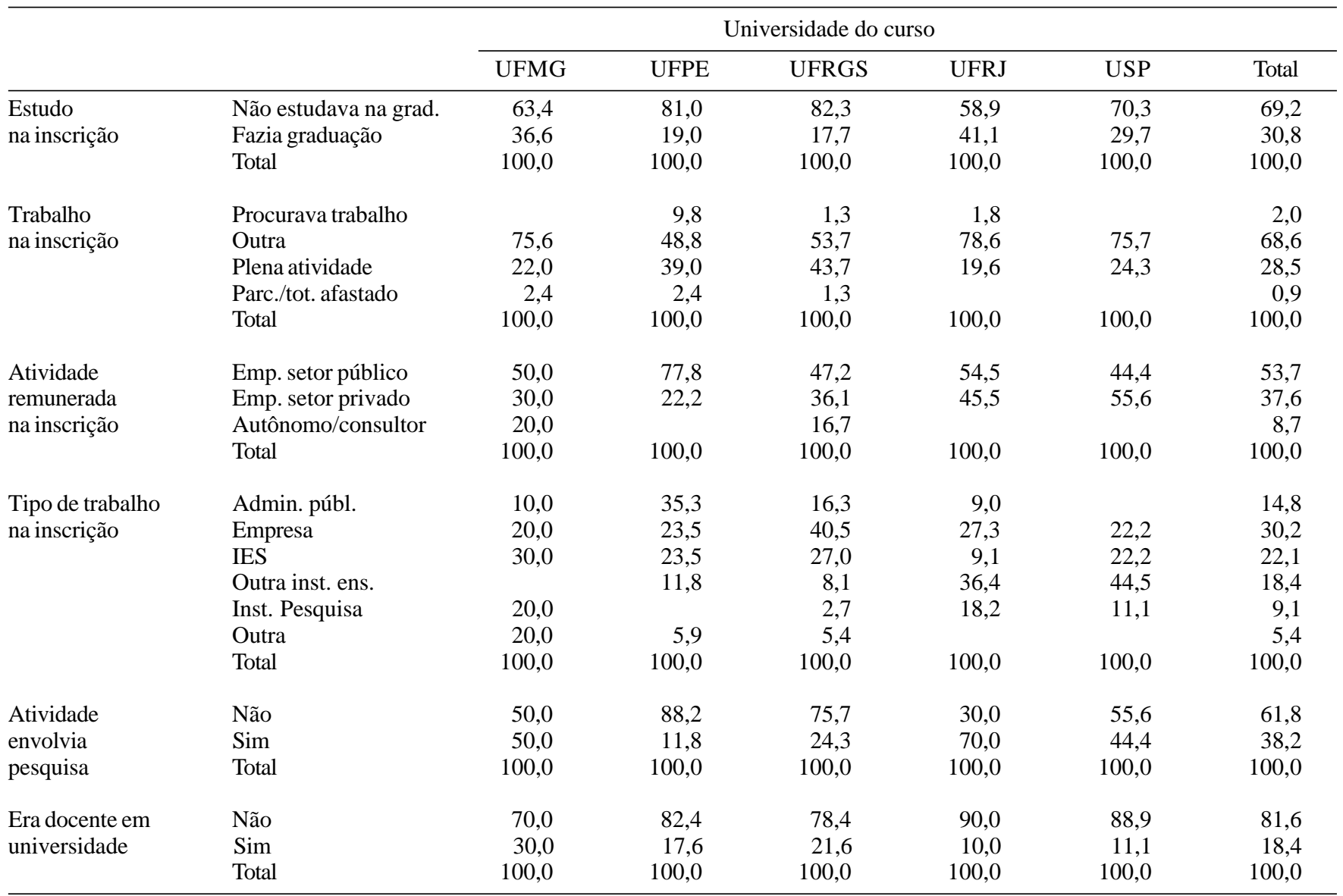


Tabela 4b. Situação de trabalho dos doutores na inscrição por universidade, percentuais

\begin{tabular}{|c|c|c|c|c|c|c|}
\hline & & \multicolumn{5}{|c|}{ Universidade do curso } \\
\hline & & UFMG & UFRGS & UFRJ & USP & Total \\
\hline \multirow{4}{*}{$\begin{array}{l}\text { Estudo } \\
\text { na inscrição }\end{array}$} & Não estudava grad./mest. & 32,8 & 84,2 & 42,9 & 34,2 & 43,2 \\
\hline & Fazia graduação & 1,6 & & 5,7 & 8,2 & 4,8 \\
\hline & Fazia mestrado & 65,6 & 15,8 & 51,4 & 57,5 & 52,0 \\
\hline & Total & 100,0 & 100,0 & 100,0 & 100,0 & 100,0 \\
\hline \multirow{5}{*}{$\begin{array}{l}\text { Trabalho } \\
\text { na inscrição }\end{array}$} & Procurava trabalho & & 5,3 & & & 0,7 \\
\hline & Outra & 70,3 & 42,1 & 74,3 & 68,9 & 67,1 \\
\hline & Plena atividade & 29,7 & 52,6 & 25,7 & 27,0 & 30,8 \\
\hline & Parc,/tot, afastado & & & & 4,1 & 1,4 \\
\hline & Total & 100,0 & 100,0 & 100,0 & 100,0 & 100,0 \\
\hline \multirow{3}{*}{$\begin{array}{l}\text { Atividade } \\
\text { remunerada } \\
\text { na inscrição }\end{array}$} & Emp, setor públ, & 84,2 & 70,0 & 88,9 & 81,8 & 81,2 \\
\hline & Emp, setor priv, & 15,8 & 30,0 & 11,1 & 18,2 & 18,8 \\
\hline & Total & 100,0 & 100,0 & 100,0 & 100,0 & 100,0 \\
\hline \multirow{6}{*}{$\begin{array}{l}\text { Tipo de trabalho } \\
\text { na inscrição }\end{array}$} & Administração públ, & & 5,0 & 22,2 & & 6,0 \\
\hline & Empresa & 10,5 & 15,0 & & 9,1 & 8,8 \\
\hline & IES & 68,4 & 80,0 & 55,6 & 72,7 & 69,6 \\
\hline & Outra inst, de ensino & 5,3 & & & & 1,2 \\
\hline & Instituição de pesquisa & 15,8 & & 22,2 & 18,2 & 14,4 \\
\hline & Total & 100,0 & 100,0 & 100,0 & 100,0 & 100,0 \\
\hline \multirow{3}{*}{$\begin{array}{l}\text { Atividade } \\
\text { envolvia } \\
\text { pesquisa }\end{array}$} & Não & 10,5 & 31,6 & 33,3 & 22,7 & 24,3 \\
\hline & Sim & 89,5 & 68,4 & 66,7 & 77,3 & 75,7 \\
\hline & Total & 100,0 & 100,0 & 100,0 & 100,0 & 100,0 \\
\hline \multirow{3}{*}{$\begin{array}{l}\text { Era docente em } \\
\text { universidade }\end{array}$} & Não & 36,8 & 20,0 & 33,3 & 31,8 & 30,6 \\
\hline & Sim & 63,2 & 80,0 & 66,7 & 68,2 & 69,4 \\
\hline & Total & 100,0 & 100,0 & 100,0 & 100,0 & 100,0 \\
\hline
\end{tabular}

mente para o doutorado, sem a conclusão do mestrado. Na UFRGS, que em relação a este aspecto apresenta situação muito diversa das demais instituições pesquisadas, concentram-se aqueles que não eram estudantes, quando foram admitidos ao doutorado.

A fração dos mestres que tinha vínculo profissional quando se inscreveu no curso é de pouco mais de 1/4 do universo considerado. Este indicador apresenta nuanças, quando se comparam as diversas instituições estudadas. Na USP, na UFMG e na UFRJ, corresponde a um percentual aproximado de $20 \%$. Por outro lado, na UFPE e na UFRGS, é da ordem de $40 \%$. Entre os que se encontravam empregados, predominavam os que atuavam no setor público em relação aos que o faziam no setor privado, característica comum a todas as instituições pesquisadas, excetuado o caso dos titulados pela USP, em sua maioria vinculados ao setor privado.

A grande maioria dos mestres, 2/3, declarou "outra situação", quando solicitada a dar informações sobre sua situação de trabalho no momento da inscrição no mestrado. Ou seja, nem estavam vinculados a atividade profissional, ainda que dela afastados, nem procuravam emprego. Aliás, a fração dos que informaram que estavam procurando emprego é muito pequena, não alcançando a $3 \%$. Entre os que se declararam em "outra situação", quase $70 \%$ tinham completado no máximo um ano de sua graduação. Ou seja, são aqueles que concluíram a graduação já com a opção definida de prosseguir estudos na pós-graduação. Para os outros $30 \%$, não deixa de ser curioso que não estivessem vinculados a uma relação profissional definida, nem estivessem procurando emprego. Como mais da metade destes últimos tinham entre 2,0 e 3,0 anos de graduado, é possível supor que parte deles, tendo já optado pelo mestrado, não obteve êxito na primeira seleção e preferiu se preparar melhor para este fim. Mas, é possível também que o percentual quase nulo relativo a opção "procurando emprego" decorra do caráter negativo a ela associado. Quem procura emprego é porque não o está encontrando com facilidade. E, para um profissional de nível superior, esta possibilidade poderia ser interpretada como resultante de um desempenho profissional insuficiente.

Menos de 20\% dos mestres que se encontravam empregados eram docentes do ensino superior. Esta percentagem é um pouco maior entre os titulados pela UFRGS e pela UFMG, especialmente neste último caso, e um pouco menor para aqueles que se formaram pela UFRJ e pela USP. A percentagem dos que responderam que sua atividade profissional envolvia pesquisa é um pouco maior, cerca de $40 \%$. Estes, como seria de esperar, se concentram entre os que trabalhavam em IES $(70 \%)$ e em institutos de pesquisa (100\%). Em contrapartida, apenas $30 \%$ dos que trabalhavam em empresas declararam que exerciam atividades de pesquisa.

A fração de doutores que tinha vínculo profissional quando se inscreveu para o doutorado é de quase 1/3 do universo entrevistado. Em relação a esse aspecto, UFMG, UFRJ e USP apresentam comportamento similar, mas na UFRGS a situação é bem diversa: a maioria de seus titulados estava em plena atividade profissional, quando se candidatou ao doutorado. A grande maioria que tinha vínculo profissional era ligada ao setor público, característica comum a todas as instituições, embora presente em menor intensidade na UFRGS.

Cerca de $70 \%$ dos doutores que tinham atividade profissional quando se inscreveram no curso atuavam em IES, quase todos eles como docentes. O segundo maior contigente é o daqueles que se en- 
contravam trabalhando em institutos de pesquisa, cerca de $15 \%$ dos que tinham vínculo profissional. Muito poucos atuavam em empresas ou na administração pública. Mais de 3/4 dos empregados desenvolviam atividades de pesquisa.

Aproximadamente 2/3 dos doutores declararam "outra situação", quando solicitados a informar sobre sua situação de trabalho ao inscrever-se para o doutorado. Essa fração corresponde a quase $90 \%$ daqueles que declararam que ainda eram estudantes àquela época. É praticamente nula a percentagem daqueles que informaram estar procurando trabalho. Apenas na UFRGS essa resposta foi registrada, duas vezes.

Quando se compara a situação profissional dos mestres e doutores em Bioquímica, no momento em que se inscreveram à pós-graduação, verifica-se uma similaridade e uma diferença. Em ambos os casos, a proporção daqueles que tinham vínculo profissional era mais ou menos a mesma, cerca de $30 \%$ dos entrevistados. No entanto, o perfil da atuação profissional, em um e outro caso, é bem diverso. No caso dos mestres, a maior parcela atuava em empresas, vindo logo a seguir o vínculo profissional com atividades relacionadas ao ensino superior, quase sempre como docente. Há ainda uma significativa fração que trabalham em "outras instituições de ensino" e na administração pública. Entre os doutores, há uma preponderância absoluta dos que trabalhavam na área acadêmica ${ }^{45}$, que representam mais de $80 \%$ dos que tinham vínculo profissional. Duas razões podem ser aventadas para este fato. A primeira delas seria a de que o doutorado é reconhecido como uma formação essencialmente direcionada para a área acadêmica, enquanto que o mestrado estaria sendo percebido como uma formação também destinada a preparar profissionais para outros ramos de atividades. Contudo, é possível uma outra interpretação. Ambos, mestrado e doutorado, estariam sendo enxergados como formações específicas para o mundo acadêmico. No entanto, o mercado de trabalho na área acadêmica só ofereceria oportunidades para aqueles que são pelo menos mestres. Sendo assim, o exercício de atividades profissionais fora desta área seria uma opção temporária, até se alcançar a qualificação necessária para a atuação no meio acadêmico. Essa segunda interpretação, como se verá um pouco mais adiante, parece a mais provável, tendo em vista as respostas obtidas quando se questionou sobre as motivações para a procura pelo mestrado.

\section{MOTIVAÇÕES PARA A PÓS-GRADUAÇÃO SENSO ESTRITO}

Uma das importantes questões da pesquisa dizia respeito às motivações para seguir a pós-graduação stricto sensu. Buscou-se identificar que aspectos mais pesaram na decisão de fazer o mestrado e o doutorado. Foram apresentados sete quesitos que poderiam ter incentivado a procura pela pós-graduação: corrigir deficiências da graduação, seguir/aprimorar carreira docente, seguir careira de pesquisador, ampliar oportunidades de trabalho, obter melhor trabalho em termos acadêmicos/profissionais, obter melhor nível de renda e aproveitar o incentivo das bolsas de estudo, solicitando-se aos entrevistados que os classificassem conforme o seu grau de importância. Os resultados obtidos encontram-se sumariados na Tabela 5. Considerar-se-ão, na análise que se segue, os principais tipos de atividade em que se concentravam os mestres e doutores em Bioquímica, quando se inscreveram na pós-graduação.

A busca do mestrado como forma de corrigir deficiências da graduação foi apontada por apenas por $1 / 4$ dos egressos como tendo pesado muito em sua decisão de fazer o curso. Em relação a este aspecto, não se observam diferenças significativas entre os segmentos considerados.

A procura de carreira docente (ou seu aprimoramento), bem como a pretensão de seguir carreira de pesquisador (ambas, aliás, em geral associadas entre si) pesaram muito na decisão de procurar o mestrado, na opinião de pelo menos $70 \%$ dos entrevistados. Como esperado, o aperfeiçoamento da carreira docente foi motivação muito importante em especial para os que atuavam em IES. Para aqueles que trabalhavam em empresas, este fator, embora tenha sido citado como muito importante por quase $3 / 5$ dos entrevistados, não apresentou a mesma relevância do que para os outros segmentos aqui considerados. Já o intuito de seguir carreira de pesquisador apresenta percentuais de resposta "muito importante", que praticamente não variaram conforme o tipo de atividade então exercida, sugerindo que aqueles que se inscrevem no mestrado na área de Bioquímica percebem esta formação como tipicamente direcionada a uma carreira de pesquisa.

A ampliação do leque de oportunidades de atuação profissional e a obtenção de um trabalho qualitativamente melhor depois do mestrado influíram muito na decisão dos entrevistados. Os que estavam vinculados a IES foram um pouco menos influenciados por estes fatores, talvez porque já tivessem encontrado uma relação profissional estável da qual não desejavam se afastar. Mas, é possível também supor que os docentes do ensino superior estavam menos otimistas quanto às possibilidades de, com o mestrado, ampliarem suas oportunidades profissionais, em comparação a aqueles que trabalhavam em empresas, na administração pública ou em outra instituição de ensino.

Surpreendentemente, considerando a elevada fração daqueles que esperavam uma situação profissional melhor após a conclusão do mestrado, apenas $40 \%$ dos titulados procuraram a pós-graduação fortemente motivados pela possibilidade de melhorar a sua remuneração. Aqui, há que se ponderar sobre aspectos culturais de nosso país. É habitual que a motivação financeira para os estudos seja vista como um aspecto pouco nobre, levando as pessoas a justificarem suas opções muitas vezes por questões um pouco vagas, como vocação ou inclinações. Não seria surpresa, se, neste quesito, o índice relativamente baixo de respostas "pesou muito" tiver sido provocado por constrangimentos em apontar uma motivação financeira para prosseguir estudos.

Coerentemente com a interpretação dada no parágrafo anterior, também se observa ser pequena a percentagem, menor que $25 \%$, daqueles que foram fortemente motivados pelo incentivo da bolsa. Quase a metade dos mestres entrevistados indicou que esse incentivo não pesou nada para a sua opção. No entanto, apenas $7 \%$ dos mestres não tiveram bolsas. Ou seja, se o incentivo da bolsa é de fato tão pouco relevante, por que seria que tão poucos concluem o mestrado sem dele usufruírem? Não seria, culturalmente falando, difícil admitir que a procura pelo mestrado se deu também em decorrência de um incentivo financeiro?

Entre os doutores, a procura pelo curso foi fundamentalmente determinada pelo desejo de ser pesquisador: quase $90 \%$ dos entrevistados declararam que este motivo pesou muito em sua escolha. Igualmente importantes, ainda que em menor intensidade, foram o desejo de seguir ou aprimorar carreira docente e a procura de melhor trabalho em termos acadêmicos e profissionais. Essas três motivações se correlacionam, uma vez que a pesquisa acadêmica em nosso país é desenvolvida essencialmente nas universidades e que o doutorado é hoje condição de ingresso em praticamente todos os departamentos de Bioquímica das universidades mais conceituadas do país. No entanto, deve ser observado que o desejo de se tornar pesquisador é um fator que motiva mais a procura pelo doutorado do que a vontade de seguir ou aprimorar carreira docente. Talvez este fato possa ser um indício de que o doutorado está mais associado à atividade de pesquisa em si do que à docência no ensino superior, que envolve pesquisa, mas não se restringe a isso. A diferença na resposta a esses dois quesitos foi maior ainda no caso daqueles que não tinham vínculo profissional quando ingressaram no doutorado: cerca de $70 \%$ deles consideraram que o fator "seguir/aprimorar carreira docente" 
Tabela 5. Motivações para o mestrado e o doutorado por principais tipos de trabalho na inscrição, percentuais

\begin{tabular}{|c|c|c|c|c|c|c|c|}
\hline & & $\begin{array}{c}\text { Adm. } \\
\text { pública }(*)\end{array}$ & $\operatorname{Empresa}(*)$ & Universidade & $\begin{array}{l}\text { Outra inst. } \\
\text { ensino(*) }\end{array}$ & $\begin{array}{r}\text { Instituição de } \\
\text { pesquisa(**) }\end{array}$ & Total $(* * *)$ \\
\hline \multicolumn{8}{|l|}{ a. Mestres } \\
\hline \multirow{3}{*}{$\begin{array}{l}\text { Corrigir deficiências } \\
\text { da graduação }\end{array}$} & Pouco/nada & 72,6 & 78,7 & 71,9 & 64,3 & & 74,4 \\
\hline & Muito & 27,4 & 21,3 & 28,1 & 35,7 & & 25,6 \\
\hline & Total & 100,0 & 100,0 & 100,0 & 100,0 & & 100,0 \\
\hline \multirow{3}{*}{$\begin{array}{l}\text { Seguir/ aprimorar } \\
\text { carreira docente }\end{array}$} & Pouco/nada & 34,3 & 42,0 & 11,5 & 33,4 & & 30,0 \\
\hline & Muito & 65,7 & 58,0 & 88,5 & 66,6 & & 70,0 \\
\hline & Total & 100,0 & 100,0 & 100,0 & 100,0 & & 100,0 \\
\hline \multirow{3}{*}{$\begin{array}{l}\text { Seguir carreira } \\
\text { de pesquisador }\end{array}$} & Pouco/nada & 25,6 & 25,7 & 24,6 & 26,4 & & 26,2 \\
\hline & Muito & 74,4 & 74,3 & 75,4 & 73,6 & & 73,8 \\
\hline & Total & 100,0 & 100,0 & 100,0 & 100,0 & & 100,0 \\
\hline \multirow{3}{*}{$\begin{array}{l}\text { Ampliar oportunida- } \\
\text { des de trabalho }\end{array}$} & Pouco/nada & 19,8 & 18,0 & 35,0 & 19,4 & & 25,7 \\
\hline & Muito & 80,2 & 82,0 & 65,0 & 80,6 & & 74,3 \\
\hline & Total & 100,0 & 100,0 & 100,0 & 100,0 & & 100,0 \\
\hline \multirow{3}{*}{$\begin{array}{l}\text { Melhor trabalho em } \\
\text { termos acadêmicos } \\
\text { ou profissionais }\end{array}$} & Pouco/nada & 14,0 & 11,4 & 29,6 & 24,0 & & 20,6 \\
\hline & Muito & 86,0 & 88,6 & 70,4 & 76,0 & & 79,4 \\
\hline & Total & 100,0 & 100,0 & 100,0 & 100,0 & & 100,0 \\
\hline \multirow{3}{*}{$\begin{array}{l}\text { Melhor nível de } \\
\text { renda }\end{array}$} & Pouco/nada & 61,0 & 70,7 & 57,7 & 47,1 & & 60,7 \\
\hline & Muito & 39,0 & 29,3 & 42,3 & 52,9 & & 39,3 \\
\hline & Total & 100,0 & 100,0 & 100,0 & 100,0 & & 100,0 \\
\hline \multirow{3}{*}{$\begin{array}{l}\text { Incentivo } \\
\text { da bolsa }\end{array}$} & Pouco/nada & 75,6 & 62,1 & 76,5 & 94,4 & & 76,6 \\
\hline & Muito & 24,4 & 37,9 & 23,5 & 5,6 & & 23,4 \\
\hline & Total & 100,0 & 100,0 & 100,0 & 100,0 & & 100,0 \\
\hline \multicolumn{8}{|l|}{ b. Doutores } \\
\hline \multirow{3}{*}{$\begin{array}{l}\text { Corrigir deficiências } \\
\text { do mestrado }\end{array}$} & Pouco/nada & & & 83,4 & & 100,0 & 88,4 \\
\hline & Muito & & & 16,6 & & & 11,6 \\
\hline & Total & & & 100,0 & & 100,0 & 100,0 \\
\hline \multirow{3}{*}{$\begin{array}{l}\text { Seguir/ aprimorar } \\
\text { carreira docente }\end{array}$} & Pouco/nada & & & 8,8 & & 100,0 & 28,1 \\
\hline & Muito & & & 91,2 & & & 71,9 \\
\hline & Total & & & 100,0 & & 100,0 & 100,0 \\
\hline \multirow{3}{*}{$\begin{array}{l}\text { Seguir carreira } \\
\text { de pesquisador }\end{array}$} & Pouco/nada & & & 14,1 & & & 12,3 \\
\hline & Muito & & & 85,9 & & 100,0 & 87,7 \\
\hline & Total & & & 100,0 & & 100,0 & 100,0 \\
\hline \multirow{3}{*}{$\begin{array}{l}\text { Ampliar oportunida- } \\
\text { des de trabalho }\end{array}$} & Pouco/nada & & & 42,1 & & 37,9 & 37,4 \\
\hline & Muito & & & 57,9 & & 62,1 & 62,6 \\
\hline & Total & & & 100,0 & & 100,0 & 100,0 \\
\hline \multirow{3}{*}{$\begin{array}{l}\text { Melhor trabalho em } \\
\text { termos acadêmicos } \\
\text { ou profissionais }\end{array}$} & Pouco/nada & & & 22,8 & & 18,5 & 24,8 \\
\hline & Muito & & & 77,2 & & 81,5 & 75,2 \\
\hline & Total & & & 100,0 & & 100,0 & 100,0 \\
\hline \multirow{3}{*}{$\begin{array}{l}\text { Melhor nível de } \\
\text { renda }\end{array}$} & Pouco/nada & & & 66,0 & & 64,5 & 67,4 \\
\hline & Muito & & & 34,0 & & 35,5 & 32,6 \\
\hline & Total & & & 100,0 & & 100,0 & 100,0 \\
\hline \multirow{3}{*}{$\begin{array}{l}\text { Incentivo } \\
\text { da bolsa }\end{array}$} & Pouco/nada & & & 92,8 & & 79,1 & 89,6 \\
\hline & Muito & & & 7,2 & & 20,9 & 10,4 \\
\hline & Total & & & 100,0 & & 100,0 & 100,0 \\
\hline
\end{tabular}

(*) - Administração pública, Empresa e Outra instituição de ensino: menos de 10\%, entre os doutores

(**) - Instituições de pesquisa : menos de $10 \%$, entre os mestres.

(***) - Os dados da coluna Total incluem outros tipos de trabalho na época da inscrição (ver Tabelas 4a e 4b) 
pesou muito em sua opção, enquanto que quase todos os entrevistados avaliaram da mesma forma o fator "seguir carreira de pesquisador". Foi também identificado como importante, embora em menor grau, o fator "ampliar oportunidades de trabalho".

A resposta a esses quesitos não difere muito, ao se cotejar aqueles que estavam vinculados a institutos de pesquisa com os que trabalhavam em instituições de ensino superior. Salvo no que se refere ao quesito "seguir ou aprimorar carreira docente", indicado como fator muito importante por mais de $90 \%$ dos docentes de ensino superior, mas que não foi escolhido por quaisquer dos doutores então vinculados a institutos de pesquisa. Curiosamente, 1/4 desses, após se titularem, tornaram-se docentes do ensino superior.

A busca do doutorado como forma de corrigir deficiências do mestrado foi apontada por pouco mais de $10 \%$ dos egressos como tendo pesado muito na sua decisão de fazer o curso. Entre aqueles que já tinham vínculo profissional com o meio acadêmico, observase uma relevância um pouco maior deste fator. Possivelmente, aqueles que estavam no meio acadêmico visualizavam a necessidade de ampliar seus conhecimentos, para uma atuação profissional de melhor qualidade, e identificaram esta necessidade como sendo uma deficiência de formação.

Similarmente ao observado para o caso dos mestres, foi surpreendentemente baixa, apenas $1 / 3$, a fração dos entrevistados que avaliaram o fator "obter melhor nível de renda" como tendo pesado muito para a decisão de cursar o doutorado. Afinal, 3/4 dos doutores haviam declarado que procuraram o doutorado fortemente motivados pela pers- pectiva de conseguirem um melhor trabalho em termos acadêmicos profissionais. E a um melhor trabalho geralmente se associa uma melhor remuneração. Provavelmente a razão para este fato seja a mesma que foi aventada no caso dos mestres: constrangimentos em apontar uma motivação financeira para prosseguir estudos.

Também entre os doutores, são poucos os que consideraram o incentivo da bolsa como tendo pesado muito em sua escolha pelo doutorado. Apenas 1/5 dos entrevistados admitem isso. No entanto, ainda similarmente ao verificado no caso dos mestres, é muito pequena, apenas $10 \%$, a proporção dos entrevistados que não foi beneficiada com bolsas de estudo. Ou seja, reforça-se a impressão de que, a despeito do que declararam mestres e doutores, o incentivo da bolsa pode sim estar sendo um fator importante para a procura pela pós-graduação estrito senso, na área de Bioquímica.

\section{ESTUDO E TRABALHO DE MESTRES E DOUTORES APÓS A TITULAÇÃO}

Entre os mestres em Bioquímica formados no país na década de 90, a continuidade da formação é uma característica dominante, conforme pode ser verificado na Tabela $6 \mathrm{a}$. Atualmente, mais da metade deles está se doutorando, a grande maioria no Brasil. Ademais, uma parte dos mestres já concluiu o seu doutorado. A soma destes fatores mestres que já se doutoraram e os que estão se doutorando - sugere que bem mais de $60 \%$ dos mestres em Bioquímica também irão concluir o doutorado $^{46}$. No entanto, a continuidade de estudos é observada em

Tabela 6a. Situação de estudo e trabalho atual dos mestres por universidade, percentuais

\begin{tabular}{|c|c|c|c|c|c|c|c|}
\hline & & \multicolumn{5}{|c|}{ Universidade do curso } & \multirow[b]{2}{*}{ Total } \\
\hline & & UFMG & UFPE & UFRGS & UFRJ & USP & \\
\hline \multirow{6}{*}{$\begin{array}{l}\text { Pós-graduação } \\
\text { após o mestrado }\end{array}$} & Faz PG lato sensu & 4,9 & & & & & 0,8 \\
\hline & Faz dout. país & 68,3 & 33,3 & 18,5 & 64,3 & 62,2 & 50,1 \\
\hline & Faz dout. sand. ou exter. & & 4,8 & & & & 0,5 \\
\hline & Faz outra PG & & 2,4 & 27,2 & 10,7 & & 10,7 \\
\hline & Não faz PG & 26,8 & 59,5 & 54,3 & 25,0 & 37,8 & 37,9 \\
\hline & Total & 100,0 & 100,0 & 100,0 & 100,0 & 100,0 & 100,0 \\
\hline \multirow[t]{5}{*}{ Trabalho } & Procura trabalho & & 2,4 & 1,4 & 1,8 & 2,7 & 1,6 \\
\hline & Outra & 63,4 & 19,0 & 27,1 & 66,0 & 51,4 & 49,9 \\
\hline & Plena atividade & 29,3 & 59,6 & 68,6 & 30,4 & 43,2 & 43,6 \\
\hline & Parc./tot. afastado & 7,3 & 19,0 & 2,9 & 1,8 & 2,7 & 4,9 \\
\hline & Total & 100,0 & 100,0 & 100,0 & 100,0 & 100,0 & 100,0 \\
\hline \multirow{4}{*}{$\begin{array}{l}\text { Atividade } \\
\text { remunerada }\end{array}$} & Emp. setor públ. & 66,7 & 84,9 & 56,9 & 66,7 & 29,4 & 61,4 \\
\hline & Emp. setor priv. & 13,3 & 12,1 & 34,5 & 22,2 & 58,8 & 28,6 \\
\hline & Outras & 20,0 & 3,0 & 8,6 & 11,1 & 11,8 & 10,0 \\
\hline & Total & 100,0 & 100,0 & 100,0 & 100,0 & 100,0 & 100,0 \\
\hline \multirow[t]{7}{*}{ Tipo de trabalho } & Admin. públ. & 20,0 & 21,2 & 19,3 & 5,6 & 5,9 & 14,8 \\
\hline & Empresa & 13,3 & 9,1 & 26,3 & 11,1 & 47,0 & 21,1 \\
\hline & IES & 33,4 & 51,5 & 42,1 & 38,8 & 23,5 & 39,4 \\
\hline & Outra inst. ens. & & 15,2 & 7,0 & 27,8 & 5,9 & 12,3 \\
\hline & Inst. pesq. & 20,0 & 3,0 & & 11,1 & 5,9 & 6,2 \\
\hline & Outras & 13,3 & & 5,3 & 5,6 & 11,8 & 6,2 \\
\hline & Total & 100,0 & 100,0 & 100,0 & 100,0 & 100,0 & 100,0 \\
\hline \multirow{3}{*}{$\begin{array}{l}\text { Atividade } \\
\text { envolve } \\
\text { pesquisa }\end{array}$} & Não & 33,3 & 51,5 & 44,8 & 38,9 & 52,9 & 44,3 \\
\hline & Sim & 66,7 & 48,5 & 55,2 & 61,1 & 47,1 & 55,7 \\
\hline & Total & 100,0 & 100,0 & 100,0 & 100,0 & 100,0 & 100,0 \\
\hline \multirow{3}{*}{$\begin{array}{l}\text { É docente em } \\
\text { universidade }\end{array}$} & Não & 66,7 & 57,6 & 61,4 & 72,2 & 76,5 & 65,9 \\
\hline & Sim & 33,3 & 42,4 & 38,6 & 27,8 & 23,5 & 34,1 \\
\hline & Total & 100,0 & 100,0 & 100,0 & 100,0 & 100,0 & 100,0 \\
\hline
\end{tabular}


percentuais bem menores, para os titulados pela UFPE e pela UFRGS. No primeiro caso, a proporção dos que fizeram ou estão fazendo doutorado é inferior a $40 \%$ e no segundo, menor do que $20 \%$. Na UFRGS, a proporção dos que estão fazendo doutorado é, inclusive, menor do que o percentual dos que estão fazendo outra pós-graduação.

Também no caso dos doutores, o prosseguimento dos estudos ocorre em proporção significativa, ainda que registrando, naturalmente, percentual bem menor do que o observado para os mestres. Conforme discriminado na Tabela $6 \mathrm{~b}$, quase $40 \%$ dos doutores entrevistados já realizaram, ou estão realizando, estágios de pós-doutorado. A frequiência observada para o pós-doutorado no exterior é 1,5 vezes maior do que a verificada no país. Este quadro apresenta grande diversidade, quando se comparam as instituições pesquisadas. Na USP, os pós-doutores chegam a representar mais de $60 \%$ dos entrevistados; na UFRGS e na UFRJ, não alcançam a 20\%. Nessas três universidades, a maioria dos pós-doutores realizou seus estágios no exterior. Na UFMG, a fração dos que se pós-doutoraram é de 1/3, com pequena preponderância da formação no país.

A Tabela $6 \mathrm{a}$ indica também que cerca de $50 \%$ dos mestres em Bioquímica têm vínculo profissional atualmente, estejam eles em plena atividade ou afastados, total ou parcialmente. Ou seja, do ponto de vista numérico, 1/3 dos que não tinham vínculo profissional quando se inscreveram para o mestrado passaram a tê-lo, após a conclusão do curso $^{47}$. Observam-se diferenças expressivas de comportamento, em relação a esta variável, nas diversas instituições pesquisadas. Na UFMG e na UFRJ, a fração dos que se encontram empregados, pouco mais de
$30 \%$, é bem menor do que a média global, enquanto que na UFPE e na UFRGS, superior a $70 \%$, é bem maior. Esse fato talvez explique o percentual bem menor de mestres formados por essas duas instituições que já se dirigiram para o doutorado, conforme já observado.

A outra metade dos mestres declarou encontrar-se em "outra situação", no que se refere a sua atividade profissional atual. Mais de $80 \%$ deles estão cursando o doutorado. Novamente, verificam-se diferenças consideráveis, quando se analisa cada instituição individualmente. Na UFMG e na UFRJ, concentram-se aqueles que se declaram em "outra situação". Isso se deve ao fato de cerca de $70 \%$ dos titulados por estas duas universidades se encontrarem vinculados a programas de doutorado. Por outro lado, a resposta "outra situação" é muito pouco freqüente na UFPE e na UFRGS, porque nestas instituições o percentual de titulados cursando o doutorado é relativamente pequeno. Ou seja, a menor fração de mestres titulados pela UFMG e pela UFRJ que se encontram empregados, comparados com os mesmos percentuais referentes à UFPE e UFRGS, pode decorrer do fato de que aqueles contam com melhores condições do que estes, para se vincularem a programas de doutorado. Na USP, o quadro observado, em relação a este aspecto, reproduz o padrão médio da área.

Entre os mestres que estão "em plena atividade", o setor público emprega a maior parte dos titulados, mais de 3/5 deles. Essa fração é mais expressiva na UFRJ e na UFPE, sendo que nesta última, mais de $4 / 5$ dos titulados com vínculo profissional estão neste setor. A atividade profissional autônoma ou de proprietário de empresas ocorre em percentual muito baixo, cerca de $10 \%$ dos que estão "em plena ativida-

Tabela 6b. Situação de estudo e trabalho atual dos doutores por universidade, percentuais

\begin{tabular}{|c|c|c|c|c|c|c|}
\hline & & \multicolumn{5}{|c|}{ Universidade do curso } \\
\hline & & UFMG & UFRGS & UFRJ & USP & Total \\
\hline \multirow{6}{*}{$\begin{array}{l}\text { Pós-graduação } \\
\text { após o doutorado }\end{array}$} & Não fez & 65,5 & 81,5 & 74,2 & 31,5 & 58,1 \\
\hline & Fazendo pós-dout. & 1,6 & & 8,6 & 2,7 & 3,7 \\
\hline & Fez pós-dout. país & 17,2 & 5,3 & 2,9 & 23,3 & 13,8 \\
\hline & Fez pós-dout. exterior & 14,1 & 13,2 & 11,4 & 37,0 & 21,3 \\
\hline & Fez PG lato sensu & 1,6 & & 2,9 & 5,5 & 3,1 \\
\hline & Total & 100,0 & 100,0 & 100,0 & 100,0 & 100,0 \\
\hline \multirow[t]{5}{*}{ Trabalho } & Procurava trabalho & 1,6 & & & 1,4 & 0,9 \\
\hline & Outra & 4,7 & 2,8 & 14,3 & 11,1 & 9,3 \\
\hline & Plena atividade & 93,7 & 97,2 & 85,7 & 84,7 & 88,8 \\
\hline & Parc./tot. afastado & & & & 2,8 & 1,0 \\
\hline & Total & 100,0 & 100,0 & 100,0 & 100,0 & 100,0 \\
\hline \multirow{4}{*}{$\begin{array}{l}\text { Atividade } \\
\text { remunerada }\end{array}$} & Emp. setor públ. & 81,6 & 83,3 & 86,7 & 76,5 & 81,4 \\
\hline & Emp. setor priv. & 16,7 & 16,7 & 13,3 & 21,9 & 17,6 \\
\hline & Outras & 1,7 & & & 1,6 & 1,0 \\
\hline & Total & 100,0 & 100,0 & 100,0 & 100,0 & 100,0 \\
\hline \multirow[t]{7}{*}{ Tipo de trabalho } & Admin. públ. & 1,7 & 5,6 & 10,0 & & 3,8 \\
\hline & Empresa & 3,3 & 2,8 & & 6,2 & 3,4 \\
\hline & IES & 81,7 & 88,8 & 80,0 & 78,1 & 81,1 \\
\hline & Outra inst. ens. & & & 3,3 & & 0,9 \\
\hline & Inst. pesq. & 13,3 & 2,8 & 6,7 & 14,1 & 10,3 \\
\hline & Outra & & & & 1,6 & 0,5 \\
\hline & Total & 100,0 & 100,0 & 100,0 & 100,0 & 100,0 \\
\hline \multirow{3}{*}{$\begin{array}{l}\text { Atividade } \\
\text { envolve } \\
\text { pesquisa }\end{array}$} & Não & 8,3 & 2,8 & 6,7 & 14,1 & 9,1 \\
\hline & Sim & 91,7 & 97,2 & 93,3 & 85,9 & 90,9 \\
\hline & Total & 100,0 & 100,0 & 100,0 & 100,0 & 100,0 \\
\hline \multirow{3}{*}{$\begin{array}{l}\text { É docente em } \\
\text { univresidade }\end{array}$} & Não & 25,0 & 11,1 & 23,3 & 21,9 & 21,5 \\
\hline & Sim & 75,0 & 88,9 & 76,7 & 78,1 & 78,5 \\
\hline & Total & 100,0 & 100,0 & 100,0 & 100,0 & 100,0 \\
\hline
\end{tabular}


de". Esse subconjunto é mais expressivo na UFMG, alcançando o percentual de $20 \%$.

O tipo de instituição em que os egressos do mestrado desenvolvem suas atividades revela bastante do que fazem. Entre aqueles que se encontram "em atividade", plena ou parcial, cerca de 2/5 atuam em instituições de ensino superior e aproximadamente $1 / 5$ trabalha em empresas. Há ainda um contigente superior a $10 \%$ trabalhando na "administração pública" e em "outra instituição de ensino", mas é surpreendentemente pequeno o percentual de mestres vinculados a "instituto de pesquisa". Quando esta variável é analisada considerando-se cada uma das instituições pesquisadas isoladamente, repete-se o quadro descrito no parágrafo anterior. Na UFRGS e, sobretudo na USP, o percentual de titulados trabalhando em empresas é relativamente elevado, enquanto que nas demais universidades predomina o vínculo com IES. Mesmo na UFRGS, onde o percentual de mestres trabalhando em empresas é maior do que $1 / 4$, a maior parte dos titulados está vinculada a IES. A existência de uma fração significativa de mestres trabalhando em empresas, contrastando com o fato de poucos doutores trabalharem em empresas - como será visto mais adiante - reproduz uma realidade igualmente observada em relação a área de Química.

Mais da metade dos mestres desenvolve atividades que envolvem pesquisa. Os titulados pela USP e pela UFPE são os que menos declararam estar envolvidos com pesquisas. Em contrapartida, essa atividade é mais freqüente entre os titulados pela UFRJ e, sobretudo, pela UFMG. Os mestres vinculados às IES e aqueles poucos que trabalham em institutos de pesquisa são os que mais desenvolvem pesquisas: no primeiro caso, cerca de 3/4 deles o fazem e, no segundo, mais de $4 / 5$. Aqueles vinculados a empresas e os que trabalham em outras instituições de ensino são os que menos pesquisam: apenas 1/4 dos que se encontram nestas situações. Talvez de forma surpreendente, quase 3/5 dos mestres trabalhando em administração pública declararam que realizam pesquisas. Cerca de $1 / 3$ dos mestres entrevistados são docentes do ensino superior. Esta fração não difere expressivamente quando se comparam as diferentes instituições pesquisadas, ainda que seja um pouco maior para a UFPE e para a UFRGS e um pouco menor para a UFRJ e a USP.

A situação atual de trabalho dos doutores em Bioquímica está sumariada na Tabela 6b. Quase $90 \%$ dos entrevistados encontram-se em plena atividade, praticamente não existindo quem esteja procurando emprego. Este quadro não se altera significativamente de instituição para instituição. A diferença mais significativa é que a propor- ção daqueles que se declararam em "outra situação" supera $10 \%$ na USP e na UFRJ e é quase nula na UFMG e na UFRGS.

A grande maioria dos entrevistados - mais de $3 / 4$ no total residem, e portanto trabalham, no mesmo estado em que se doutoraram, característica presente em todas as universidades consideradas neste estudo. Esta situação não se altera, quando se consideram especificamente aqueles que tinham vínculo profissional à época em que se inscreveram para o doutorado. Ou seja, parece que, no que se refere à formação de pós-graduados na área de Bioquímica, as universidades, inclusive a USP, ou atraem estudantes essencialmente na região em que se localizam ou aqueles que mudaram de estado para estudar não regressaram para os seus estados de origem, após se titularem.

A atividade profissional atual dos doutores é essencialmente na área acadêmica e no setor público. Mais de 3/4 dos entrevistados são docentes de IES e mais de $90 \%$ deles estão desenvolvendo atividades de pesquisa. Não se observam diferenças expressivas entre as instituições pesquisadas com referência a essas questões.

\section{A TRAJETÓRIA: DE ONDE VIERAM E ONDE ESTÃO OS MESTRES E DOUTORES EM BIOQUÍMICA}

Outra questão de interesse da pesquisa era identificar características da trajetória dos egressos após sua titulação: de onde vieram e para onde foram? A resposta à indagação indica que o destino predominante dos egressos é a academia, seja como atuação profissional, seja como continuidade de sua formação ${ }^{48}$, conforme os resultados da Tabela 7.

Quando da inscrição ao mestrado, quase 3/4 dos entrevistados eram inativos. Este fato decorre de que uma boa parte deles, cerca de $1 / 3$, ainda cursava a graduação nesta época, enquanto que quase outro tanto havia se graduado recentemente. Após a conclusão do mestrado, 1/3 dos anteriormente inativos declararam vínculo profissional permanente, a maioria deles no meio acadêmico. Mas, entre os exinativos, observa-se também um pequeno contingente que ocupa postos de trabalho no mercado e no estado.

Levando-se em conta que cerca de $80 \%$ dos mestres que permanecem inativos após concluírem o mestrado estão cursando o doutorado, é possível identificar uma tendência de reorientação profissional associada à conclusão do mestrado, direcionada para a academia. Entre os que se encontravam empregados quando se inscreveram para a pósgraduação, $40 \%$ passaram a ter atividade diferente após o mestrado, sendo que $7 \%$ migraram para o mercado, $3 \%$ para o estado, $5 \%$ para a

Tabela 7. Mercado, estado ou academia: trajetória de mestres e doutores da inscrição à situação atual, percentuais

\begin{tabular}{|c|c|c|c|c|c|c|c|}
\hline & & \multicolumn{5}{|c|}{ Situação e locus laboral atualmente } & \multirow[b]{2}{*}{ Tota } \\
\hline & & Mercado & Estado & Academia & Inativo & Desempregado & \\
\hline \multicolumn{8}{|l|}{ a. Mestres } \\
\hline Situação e locus & Mercado & 4,1 & 0,8 & 0,5 & 3,6 & & 9,0 \\
\hline \multirow{5}{*}{ laboral na inscrição } & Estado & 0,5 & 2,3 & 0,9 & 1,4 & & 5,0 \\
\hline & Academia & 1,3 & & 7,7 & 1,4 & & 10,4 \\
\hline & Inativo & 6,3 & 5,0 & 13,1 & 47,5 & 1,4 & 73,3 \\
\hline & Desempregado & & & 0,9 & 0,9 & 0,5 & 2,3 \\
\hline & Total & 12,2 & 8,1 & 23,1 & 54,8 & 1,8 & 100,0 \\
\hline \multicolumn{8}{|l|}{ b, Doutores } \\
\hline Situação e locus & Mercado & 0,5 & & 2,4 & & & 2,9 \\
\hline \multirow[t]{5}{*}{ laboral na inscrição } & Estado & & 1,4 & 0,5 & & & 1,9 \\
\hline & Academia & 1,0 & 0,5 & 24,2 & 1,4 & & 27,1 \\
\hline & Inativo & 1,9 & 1,4 & 55,6 & 7,2 & 1,0 & 67,1 \\
\hline & Desempregado & & 0,5 & 0,5 & & & 1,0 \\
\hline & Total & 3,4 & 3,4 & 83,1 & 9,2 & 1,0 & 100,0 \\
\hline
\end{tabular}


academia e $25 \%$ tornaram-se inativos. Somando-se os percentuais associados à mudança para a área acadêmica e aos que passaram a inativos, em sua grande maioria alunos de doutorado ${ }^{49}$, verifica-se que $30 \%$ dos que tinham atividade profissional quando foram admitidos para o mestrado, migraram de outra atividade para a área acadêmica. Em contrapartida, $13 \%$ dos que se encontravam vinculados à academia no momento da inscrição migraram para outras áreas, após a conclusão do mestrado. Somando-se ponderadamente esses dois movimentos — de entrada e de saída da área acadêmica — e considerando os percentuais de inativos que são alunos de doutorado e o de doutores que estão no meio acadêmico, verifica-se um percentual médio líquido de $14 \%$ de migração de outras áreas para a academia.

Em adição a esta reorientação profissional para a área acadêmica, a conclusão do mestrado também orienta fortemente para essa área aqueles estudantes que ingressaram no mestrado sem ter um vínculo profissional definido. Destes, $66 \%$ permanecem como inativos após o mestrado, $9 \%$ dirigem-se para o mercado, $7 \%$ para o estado e $17 \%$ para a academia. Considerando-se que cerca de $3 / 4^{50}$ dos mestres atualmente inativos deverão estar, dentro de alguns anos, atuando no meio acadêmico, conclui-se que mais de $60 \%$ daqueles que ingressaram no mestrado sem vínculo profissional se orientarão profissionalmente para a academia.

Já em relação aos doutores, observa-se que a conclusão do curso não reorienta opções profissionais. Procuram o doutorado em Bioquímica quase que exclusivamente profissionais que já estavam vinculados ao meio acadêmico - e estes assim permanecem após o doutoramento - e estudantes de mestrado, os quais, em sua quase totalidade, quando se tornam doutores, passam a atuar na área acadêmica. Quando da inscrição ao doutorado, 2/3 dos entrevistados eram inativos. Este fato decorre de que a grande maioria deles, cerca de 3/4, ainda cursava o mestrado nesta época. Os demais entrevistados, em sua quase totalidade, encontravam-se vinculados ao meio acadêmico. Após a conclusão do doutorado, a percentagem de inativos reduz-se a menos de $10 \%$ e a de desempregados não alcança a $1 \%$. Os que eram inativos agora atuam no meio acadêmico, com poucas exceções, e essas se concentram entre aqueles que permanecem inativos. Os que permanecem hoje como inativos, quase todos, concluíram o doutorado no período 96/98 e/ou estão fazendo pós-doutorado ou terminaram o pós-doutorado recentemente. Ademais, eles se concentram entre os titulados pela USP e pela UFRJ, sendo raros na UFMG e na UFRGS ${ }^{51}$.

Cabe ainda um comentário em relação à atividade profissional dos doutores em Bioquímica. Como visto, o doutorado nesta área tem como objetivo precípuo a preparação de profissionais qualificados para o meio acadêmico, o que significa dizer para as universidades, em sua grande maioria. E para as universidades do setor público, uma vez que a pós-graduação no país, em especial em áreas de "hard science" como é a Bioquímica, está concentrada neste setor. Ocorre que, nos últimos anos, o setor das federais praticamente não está admitindo professores e as estaduais paulistas também enfrentam dificuldades nesta questão ${ }^{52}$. A permanecer esta situação por um tempo maior, tal fato poderá ter impacto muito negativo no doutorado em Bioquímica. Seja ocasionando uma redução pronunciada na procura, seja desestimulando os estudos daqueles que, a despeito de uma perspectiva profissional desfavorável, ainda continuarem a procurar o doutorado, em razão da bolsa ou atendendo a uma forte inclinação profissional.

Com relação ao setor de trabalho de mestres e doutores em Bioquímica, antes e depois da titulação, o que se observa é que o término da pós-graduação favorece amplamente a atuação no setor público, conclusão a que se pode chegar cotejando as Tabelas 4 a e 6 a e as Tabelas $4 \mathrm{~b}$ e $6 \mathrm{~b}$. Antes de iniciarem o mestrado, $29 \%$ dos mestres encontravam-se ativos profissionalmente, sendo $16 \%$ deles na área pública e $13 \%$, na área privada ${ }^{53}$. Após a conclusão do curso, $49 \%$ deles têm vínculo profissional definido, sendo $30 \%$ no setor público e $19 \%$, no privado. Os números são ainda mais expressivos, no caso do doutorado. Ao ingressarem no curso, $32 \%$ dos doutores eram ativos profissionalmente, sendo $26 \%$ na área pública e $6 \%$ na privada. Após a conclusão do doutorado, $90 \%$ têm vínculo profissional definido, sendo $73 \%$ no setor público e $17 \%$, no privado.

\section{QUANTO ESTÃO GANHANDO OS MESTRES E DOUTORES EM BIOQUÍMICA?}

Solicitou-se aos entrevistados que declarassem sua renda pessoal, classificando-a em uma das seis faixas de valores em reais apresentadas. A menor faixa foi de até $\mathrm{R} \$ 1.500,00$ e a maior, superior a $\mathrm{R} \$ 5.500,00$. As rendas médias foram calculadas tomando-se o ponto médio do intervalo de valores que definiam a faixa. Para o caso das duas faixas extremas - superior e inferior - adotou-se o critério de manter constante, em $\mathrm{R} \$ 1.000,00$, a diferença entre a renda média de duas faixas subseqüentes.

A renda média para os mestres é cerca de $R \$ 2,4$ mil. Os que atuam em IES e na administração pública (e também a pequena parcela dos que trabalham em institutos de pesquisa) têm renda semelhante, em torno de R \$ 2,1 mil mensais, conforme descrito na Figura 4 , na qual se discriminam apenas os tipos de trabalho relatados por mais de $10 \%$ dos mestres. Esse valor é bem abaixo do que o declarado pelos que trabalham em empresas, R\$ 3,3 mil. Como seria de esperar, a renda aumenta com a experiência profissional. Os titulados nos dois primeiros anos da década registram ganhos médios de quase $\mathrm{R} \$ 3,4$ mil, contra pouco mais de $\mathrm{R} \$ 2,0$ mil, para os que concluíram o mestrado nos dois últimos anos do período considerado. Ou seja, uma diferença de aproximadamente 70\%. O aumento da renda média com a experiência profissional é aproximadamente linear, coeficiente de correlação de 0,85 , correspondendo a um acréscimo de R\$240,00, em média, por ano de experiência.

A renda média mensal dos mestres varia expressivamente conforme a instituição que titulou o entrevistado. Aqueles que se formaram pela UFMG e pela UFPE são os que menos ganham, cerca de R $\$ 2,0$ mil. Este valor cresce um pouco para os titulados pela UFRJ e UFRGS, cerca de $\mathrm{R} \$ 2,3$ e 2,5 mil, respectivamente. Já os que se formaram pela USP têm renda média bem superior, R \$ 3,4 mil. Um dos fatores que explicam estas diferenças é o tipo de atividade desenvolvida pelos mestres titulados em cada instituição ${ }^{54}$. É razoável ainda supor que estas diferenças tenham a ver também com os padrões de remuneração dos diversos estados da Federação, uma vez que mais de $90 \%$ dos entrevistados residem no mesmo estado onde concluíram o mestrado.

Os mestres que se encontram empregados no setor privado recebem em média $40 \%$ a mais do que seus colegas do setor público. Se a comparação for feita com todos aqueles vinculados ao setor privado,

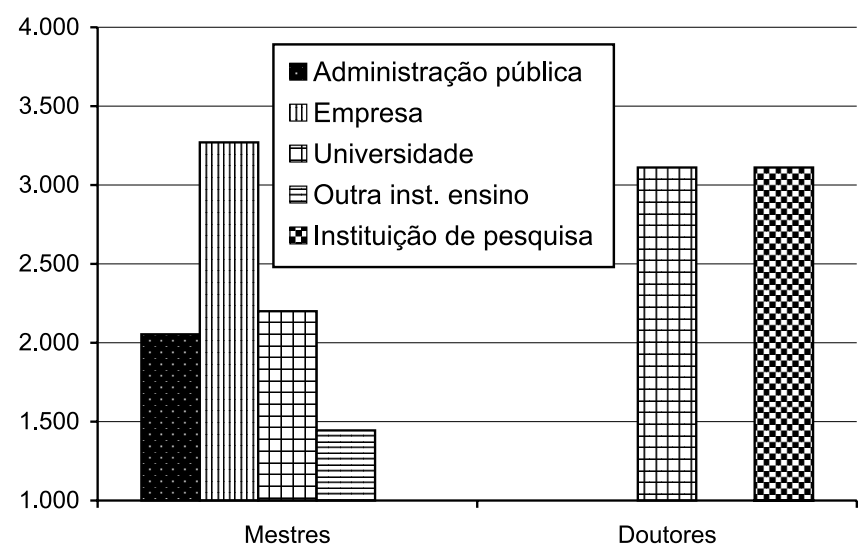

Figura 4. Médias de renda, em reais, por principais tipos de trabalho 
incluindo os que exercem atividades autônomas ou empresariais, essa diferença sobe para 50\%. Uma diferença de remuneração tão elevada, acredita-se, deveria merecer a atenção das autoridades responsáveis. Na medida em que esta situação se consolide, é possível que o setor público perca a capacidade de atrair os profissionais de melhor desempenho para os seus quadros.

A renda média registrada pelos mestres guarda alguma correlação com a escolaridade de seus pais. Aqueles que são filhos de pais, ou mães com escolaridade de, no máximo, o primeiro grau completo ${ }^{55}$ relatam ganhos que são cerca de $20 \%$ menores do que os observados para filhos de pais com maior nível de escolaridade. Entretanto, essa diferença praticamente desaparece quando se comparam os filhos de pais que concluíram apenas a escola média com aqueles cujos pais são graduados.

Para os doutores, a renda média é cerca de $\mathrm{R} \$ 3,1$ mil, o que corresponde a um acréscimo de $30 \%$ em relação à dos mestres. Os maiores rendimentos são auferidos por aqueles poucos que trabalham na administração pública e os menores, pelos também raros empregados de empresas, invertendo-se o observado para o caso dos mestres, cujos salários são maiores nas empresas. É interessante registrar que a renda média dos doutores que trabalham em empresas é cerca de $30 \%$ menor do que a dos mestres na mesma situação. Ou seja, parece que as empresas valorizam mais os mestres do que os doutores $^{56}$. Instituições de ensino superior e institutos de pesquisa têm padrão salarial similar, conforme se pode verificar na Figura 4. Ao contrário do que se verificou para o caso dos mestres, cuja remuneração é expressivamente maior no setor privado, os rendimentos médios pagos pelos setores público e privado são muito próximos: cerca de 5\% maiores na área pública, em comparação com a área privada.

Também ao contrário do que se verificou em relação aos mestres, a renda média é praticamente independente da instituição formadora. Quando tal comparação é feita, observa-se que a diferença entre a maior e a menor remuneração é de $2 \%$. Certamente, isso reflete o fato de a quase totalidade dos doutores em Bioquímica trabalharem na área acadêmica e em instituições públicas, com planos de cargos e salários muito similares, se não idênticos.

A renda média dos doutores mostra também tendência de aumentar com a experiência profissional, mas essa tendência é menos pronunciada do que no caso dos mestres. Os doutores da coorte de 1990 percebem apenas $30 \%$ a mais do que seus colegas da coorte de 1998, enquanto que no caso dos mestres esta diferença alcança $100 \%$. Não se observa também a dependência linear entre renda média e tempo de experiência profissional. Mais uma vez este comportamento talvez possa ser creditado ao fato de os doutores atuarem, quase todos, no meio acadêmico.

A remuneração média dos doutores, diferentemente do que foi observado para os mestres, não é afetada pelo nível de escolaridade de seus pais. De certa forma, isso seria esperado, tendo em vista que a grande maioria dos doutores atuam na área acadêmica e no setor público, sujeitos a planos de cargos e salários geralmente bem definidos. Essa diferença observada em relação ao verificado para os mestres sugere que a remuneração auferida fora do meio acadêmico possa estar sendo influenciada também por questões de relações pessoais ${ }^{57}$. Talvez essa questão possa ser investigada no futuro, para se agregar um novo elemento, no que diz respeito aos condicionantes que determinam a remuneração de pós-graduados em nosso país.

A remuneração tanto de mestres como de doutores, daqueles mais do que destes, é afetada pelo sexo dos titulados. Seguindo o padrão habitual — comum à maioria das atividades profissionais — as mulheres ganham menos do que os homens. As diferenças percentuais, tomando a remuneração dos homens como referência, é de cerca de $15 \%$, no caso dos doutores e de $30 \%$, no caso dos mestres. Uma explicação sobejamente conhecida para essas diferenças entre gêneros é o caráter "machista" de nossa sociedade, apesar do universalismo da legislação em vigor. No caso em tela, entretanto, apenas esse aspecto talvez seja insuficiente para explicar o que foi observado.

Ocorre que as diferenças de remuneração entre homens e mulheres são observadas em praticamente todo o tipo de atividade desenvolvida por mestres e doutores em Bioquímica, inclusive no ensino superior, ainda que sejam mais expressivas nas empresas e na administração pública. Isso é inesperado, uma vez que no ensino superior, em especial na área pública, existem planos de carreiras bem definidos, que não discriminam as mulheres. É observada ainda em todas as instituições pesquisadas, à exceção dos doutores formados pela UFRJ, para os quais a remuneração das mulheres é 3\% maior do que a dos homens. A maior remuneração dos homens não pode ser atribuída ao maior tempo de titulação destes, visto que as diferenças em relação a esse último aspecto, embora existentes, são muito pequenas e sem significado estatístico. Não foi possível encontrar um fator que pudesse representar uma explicação plausível para essa regularidade, com os dados colhidos na pesquisa. Certamente, pode-se imaginar diversas razões que contribuiriam para isso, mas todas elas são de natureza subjetiva e impossíveis de ser comprovadas com as informações de que dispomos ${ }^{58}$

\section{CONTRIBUIÇÕES DA PÓS-GRADUAÇÃO PARA O TRABALHO ATUAL}

Uma questão-chave da pesquisa referia-se às relações entre a formação recebida e o trabalho que desenvolviam na época em que foram coletados os dados. Que contribuições teve o curso para o trabalho atual, segundo a percepção dos egressos? As experiências de trabalho após o curso correspondem às expectativas da época da inscrição? Foram apresentados aos entrevistados quatro quesitos para serem avaliados, conforme a contribuição que estariam tendo para o seu exercício profissional atual: formação teórica, experiência em pesquisa, atualização/reciclagem de conhecimentos e contatos acadêmicos e profissionais. A súmula das respostas a essas questões encontra-se registrada nas Figuras $5 a$ e 5b, sendo discriminadas conforme o tipo de trabalho atual do entrevistado ${ }^{59}$, com registro apenas para aquelas atividades que congregam mais de $10 \%$ dos mestres ou dos doutores.

Em geral, os mestres em Bioquímica indicam elevado grau de satisfação com o curso que fizeram. Para $70 \%$ deles, a formação teórica e a reciclagem de conhecimentos têm contribuído muito para o seu exercício profissional. Os que são docentes são os que melhor avaliam o impacto desses quesitos. Por outro lado, aqueles que trabalham em empresas ou na administração pública são bem menos otimistas em relação a esses aspectos. Para mais da metade desses últimos, eles não contribuíram muito para o seu exercício profissional.

A experiência em pesquisa foi considerada, pelo mestres, como de maior importância do que a formação teórica, trazendo elevada contribuição para as atividades profissionais de quase $80 \%$ deles. Em relação a esse quesito, a opinião varia muito pouco, conforme o tipo de trabalho atual: os percentuais correspondentes para a resposta "contribuiu muito" oscilam entre $70 \%$ e $85 \%$. Ele foi o fator apontado como o mais importante, para todos os tipos de trabalho considerados, excetuados aqueles que atuam como docentes, mas não no ensino superior. Para estes últimos, provavelmente em sua grande maioria professores do ensino médio, a experiência em pesquisa é superada tanto pela formação teórica, quanto pela reciclagem de conhecimentos, o que parece ser bastante natural. Tal nível de relevância atribuído à variável "experiência em pesquisa" parece coadunar-se com o principal motivo para a busca do mestrado em Bioquímica, qual seja a carreira de pesquisador. 


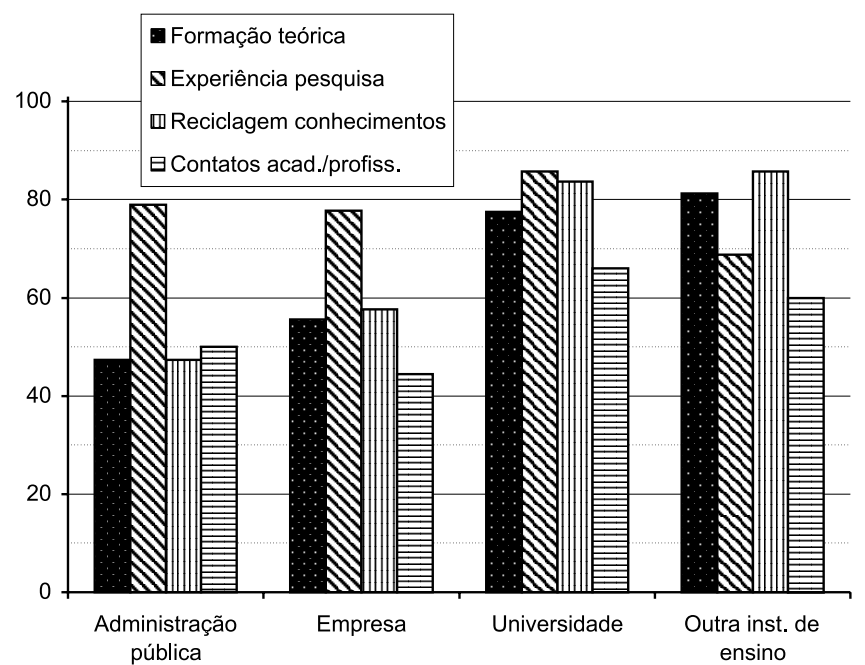

Figura 5a. Contribuições do mestrado para os principais tipos de trabalho; percentual de "contribuiu muito"

Os contatos acadêmicos e profissionais advindos do mestrado foram identificados como o fator que menos contribuiu para o exercício profissional. No entanto, excetuados os que trabalham em empresa, pelo menos a metade dos entrevistados consideram que eles estão sendo muito importantes para o seu exercício profissional. No caso dos que estão profissionalmente vinculados à administração pública, a importância desse fator foi similar à observada para a formação teórica e para a reciclagem de conhecimentos.

$\mathrm{O}$ conjunto das percepções revela, portanto, que o concurso da formação obtida tem sido elevado para o bom desenvolvimento das atividades profissionais dos mestres. Considere-se também que o mestrado teria na qualificação para a docência no ensino superior uma de suas principais finalidades - senão a principal - e que, nesta ordem de idéias, são exatamente os docentes que freqüentemente se destacam na avaliação das relações entre formação e trabalho atual, com as apreciações mais positivas. No entanto, observam-se algumas reiteradas diferenças nos níveis dos aportes da formação teórica e da reciclagem de conhecimentos que o curso propiciou, para as quais os mestres atuando em empresas e na administração pública, nesta ordem, têm avaliações bem inferiores às dos professores. Considerando-se ainda a parcela dos mestres que trabalham em empresas (cerca de $20 \%$ daqueles que hoje são ativos profissionalmente) ou na administração pública (aproximadamente 15\% do mesmo universo), os resultados parecem sugerir que haveria espaço para melhorias na formação dos mestres em Bioquímica, talvez introduzindo alguma diversificação que atendesse mais de perto os que futuramente se dirigiriam ao mercado de trabalho das empresas, públicas e privadas, e da administração pública.

O grau de satisfação dos doutores com o curso que fizeram é mais elevado ainda do que o dos mestres. Todos os quesitos apresentados foram indicados pela grande maioria dos entrevistados como tendo contribuído muito para a sua formação. O quesito "experiência em pesquisa" se destaca em relação aos demais, sendo citado como "tendo contribuído muito" por cerca de 95\% dos entrevistados. Esse resultado guarda correspondência com o fato de a maior motivação para a procura do doutorado ser o desejo de seguir carreira de pesquisador. Aqueles que atualmente trabalham em empresas são os que menos classificaram esse quesito como "tendo contribuído muito" ${ }^{60}$. Isso é coerente com a observação de que são exatamente esses profissionais os que menos desenvolvem atividades de pesquisa hoje $\mathrm{e}^{61}$.

Os outros quesitos sugeridos aos entrevistados mostraram res-

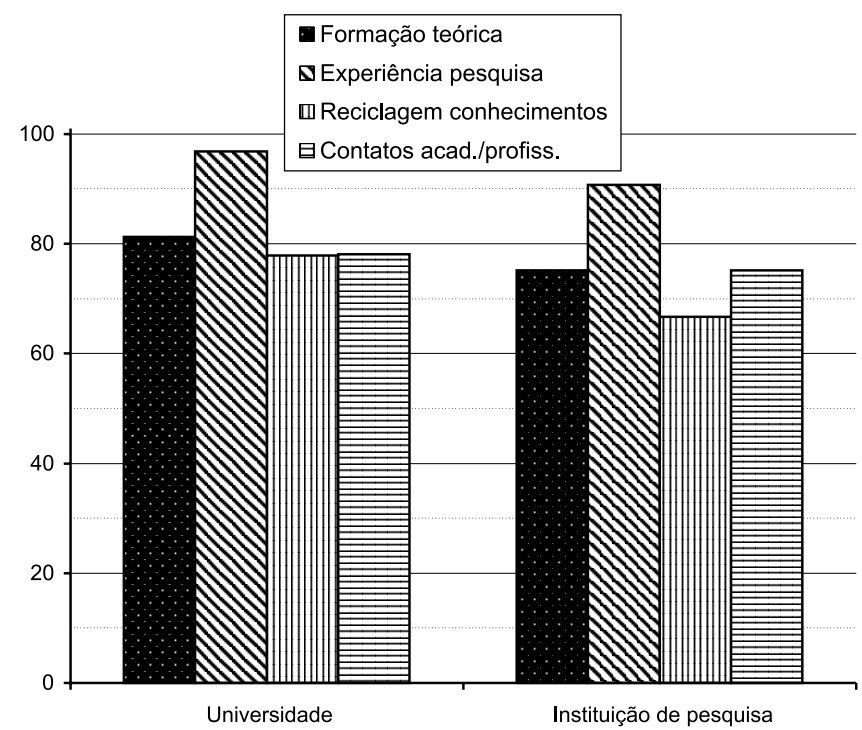

Figura 5b. Contribuições do doutorado para os principais tipos de trabalho; percentual de "contribuiu muito"

postas similares: cerca de 3/4 dos doutores classificaram todos eles como "tendo contribuído muito". Aqueles que trabalham em empresas têm avaliações sistematicamente menos positivas. Os que atuam na administração pública não consideraram a formação teórica como um fator tão relevante quanto os seus colegas de outras instituições. Por sua vez, os vinculados a institutos de pesquisa consideraram a reciclagem de conhecimentos como o fator menos relevante para a sua formação, da mesma forma que a grande maioria dos que trabalham em IES, embora a avaliação destes últimos em relação a esse quesito seja melhor do que a dos primeiros. Os contatos acadêmicos e profissionais foram considerados, pelos que atuam em IES, de forma similar à reciclagem de conhecimentos.

\section{O IMPACTO DA PÓS-GRADUAÇÃO NA VIDA PROFISSIONAL: O QUE MUDA DEPOIS?}

Indagou-se também se a formação no mestrado e no doutorado trouxe mudanças em alguns aspectos relevantes do trabalho dos egressos, comparando-se sua situação antes e depois do curso, procurando-se avaliar se ocorreram alterações e, em caso positivo, em que medida estas atenderam às expectativas que tinham os egressos quando se inscreveram na pós-graduação. Os resultados encontrados ${ }^{62}$ estão apresentados nas Figuras $6 \mathrm{a}$ e $6 \mathrm{~b}$.

As informações prestadas pelos mestres revelam que o curso teve impactos positivos na vida profissional, sugerindo um cenário de elevada satisfação com as mudanças propiciadas ${ }^{63}$. Cerca de metade dos mestres julga que, depois do curso, suas oportunidades de trabalho tiveram grande aumento e quase $3 / 4$ entendem que seu trabalho atual, do ponto de vista acadêmico e/ou profissional, é muito melhor do que antes. Destacam-se, nesta apreciação positiva, os que atuam em IES e na administração pública. Quanto ao nível de renda, quase $60 \%$ dos mestres entendem que este aumentou muito depois do curso, novamente com destaque para os que hoje atuam nas duas áreas mencionadas anteriormente. Os que trabalham em empresas, em outra instituição de ensino e em institutos de pesquisa são os que identificam impacto menos positivo do mestrado em seu nível de renda. Por outro lado, os docentes do ensino superior são os que mais associam um aumento expressivo da renda com a conclusão do mestrado. De uma maneira geral, os mestres que trabalham em empresa são os 


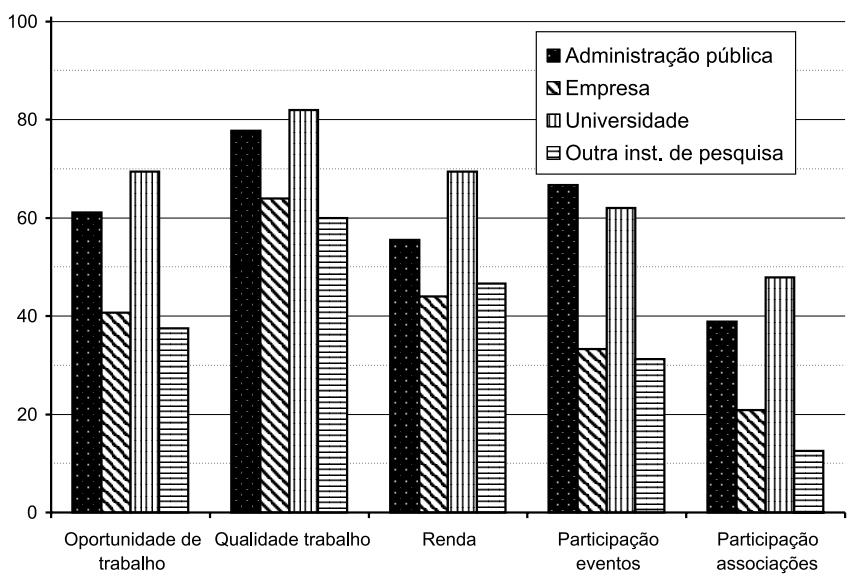

Figura 6a. Impacto do mestrado na atividade profissional; percentual de melhorou muito

menos otimistas na avaliação do curso e os docentes do ensino superior, aqueles que o fazem de forma mais positiva.

Cerca da metade dos mestres também declarou que sua participação em eventos científicos hoje é muito maior do que quando ingressaram no mestrado. Uma fração bem menor, $1 / 5$, julga que ela é apenas um pouco maior. Esses resultados parecem ser coerentes com os demais dados colhidos neste trabalho. Mas, por outro lado, chega a surpreender o fato de $1 / 3$ dos entrevistados considerarem que sua participação em eventos hoje não é maior do que antes de sua admissão no mestrado. É bem verdade que estes se concentram entre aqueles cujo vínculo profissional é com empresas ou com instituições de ensino que não são de terceiro grau. Ainda assim, mais de $20 \%$ daqueles cujo vínculo profissional atual é com IES também informam que sua participação em eventos não aumentou, quando comparada com a que tinham ao ingressarem no mestrado. E isto, evidentemente, não seria de se esperar.

As informações prestadas pelos doutores revelam que o curso teve impactos positivos na vida profissional, sugerindo também um cenário de elevada satisfação com as mudanças propiciadas pelo curso, conforme discriminado na Figura 6b. Cerca de 2/3 dos doutores julga que, depois do curso, suas oportunidades de trabalho tiveram grande aumento e quase 3/4 entendem que seu trabalho atual, do ponto de vista acadêmico e/ou profissional, é muito melhor do que antes ${ }^{64}$. Não há diferenças significativas nessa avaliação entre docentes de ensino superior e pesquisadores de institutos de pesquisa.

Mais de $60 \%$ dos doutores entrevistados consideraram que a sua renda atual é muito superior à que auferiam antes do doutorado. Os professores do ensino superior avaliam esse quesito de forma um pouco mais positiva do que seus colegas que têm vínculos profissionais com institutos de pesquisa, ainda que a renda média desses dois grupos seja praticamente a mesma.

Avaliações desfavoráveis em todos os quesitos, no entanto, são a tônica entre aqueles que desenvolvem atividades profissionais em empresas. Estas, provavelmente decorrem da remuneração muito baixa desses profissionais, conforme já visto, e do fato de apenas $40 \%$ deles desenvolverem atividades de pesquisa atualmente.

O doutorado contribui apenas medianamente para aumentar a participação em eventos e em associações científicas e profissionais. Muito provavelmente porque a formação do mestrado também já requer uma participação ativa nessas atividades.

\section{CONCLUSÕES}

Os mestres e doutores em Bioquímica são egressos preferencial-

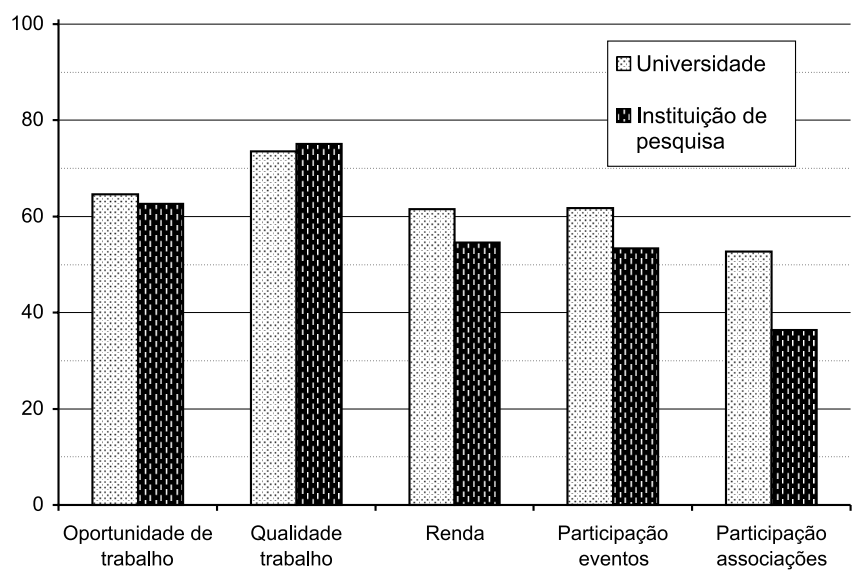

Figura 6b. Impacto do doutorado na atividade profissional; percentual de melhorou muito

mente de cursos de graduação na área de Biologia, mas existe uma contribuição significativa de áreas conexas da graduação, em especial Farmácia, Química e Medicina, sobretudo no caso dos doutores. Entre os titulados na década de 90 , há preponderância do sexo feminino: as mulheres correspondem a aproximadamente $3 / 4$ dos mestres e a quase $60 \%$ dos doutores.

O ingresso no mestrado ocorre cerca de 3 anos após a graduação, mas esta média apresenta grande dispersão, o que caracteriza a coexistência de trajetórias diferentes, embora $70 \%$ dos titulados tenham sido admitidos no curso até dois anos após se graduarem. Isso também é observado para o doutorado, que se inicia, em média, cerca de 6 anos após a graduação. Aqueles que fizeram anteriormente o mestrado ingressam no doutorado praticamente em seguida à conclusão do mestrado, em torno de 7 anos após se graduarem. Os que foram diretamente para o doutorado o fazem cerca de 3 anos após concluírem a graduação. Há indícios de que o tempo médio decorrido entre a conclusão da graduação e o ingresso na pós sofreu uma redução nos últimos anos, de aproximadamente $10 \%$, tanto para o mestrado quanto para o doutorado.

A duração média do mestrado é de 3 anos, valor que decresceu expressivamente ao longo da década: cerca de $40 \%$, quando se comparam os anos inicial e final do período estudado. Entretanto, não se verifica diminuição da idade média de titulação, que é de 30 anos. A menor duração do curso e o ingresso no mestrado mais próximo da graduação estão sendo compensados por um acréscimo na idade média de graduação, que passou de cerca de 22 anos para quase 25 anos. Já no caso do doutorado, o curso tem duração média de 4,5 anos, valor que não se alterou significativamente ao longo da década e que praticamente é o mesmo para todas as instituições pesquisadas. A idade média de titulação é cerca de 34 anos. Observa-se uma expressiva diferença nessa média quando se comparam os entrevistados que previamente concluíram o mestrado com os que foram diretamente para o doutorado, respectivamente 35 anos e 31 anos.

Considerando-se o nível de instrução dos pais, a origem socioeconômica dos titulados é bastante diversificada, ao contrário do que se poderia esperar. Cerca $30 \%$ dos mestres e de $40 \%$ dos doutores são filhos de pai ou mãe com instrução superior. Por outro lado, cerca de 1/3, em ambos os casos, são filhos de pai ou de mãe cuja instrução é, no máximo, a de primeiro grau completo. Apenas $15 \%$, entre os doutores e também entre os mestres, possuem mãe e pai, ambos, com nível de instrução superior. São raros aqueles cujo pai ou mãe fizeram mestrado ou doutorado.

Apenas 1/3 dos mestres tinham vínculo profissional quando se inscreveram para o mestrado. Estes, distribuíam-se de forma quase 
eqüitativa entre os setores público e privado. Quase 20\% eram docentes do ensino superior e cerca de $40 \%$ desenvolviam atividades de pesquisa. Após a conclusão do mestrado, observa-se que $60 \%$ deles permanecem na pós-graduação, agora como estudantes de doutorado, e que a metade tem vínculo profissional, dos quais $2 / 3$ atuam no setor público e 1/3, no privado. Ou seja, o mestrado redireciona ocupações da área privada para a área pública. Da mesma forma, aqueles que passaram a ter atividade profissional após o mestrado encontram-se preferencialmente no setor público. Dos que estão em atividade, $40 \%$ atuam em instituições de ensino superior, cerca de $20 \%$ trabalham em empresas e mais de $60 \%$ declararam que desenvolveram atividades de pesquisa nos últimos 3 anos. A grande maioria deles (mais de 80\%), por meio de projetos com financiamento, mas apenas uma pequena proporção, cerca de $20 \%$, na qualidade de coordenadores destes projetos.

Também apenas $1 / 3$ dos doutores tinha vínculo profissional quando se inscreveu para o doutorado. Mais da metade deles ainda era estudante, a quase totalidade, de mestrado. A grande maioria dos que trabalhavam atuava no setor público, quase que invariavelmente em universidades ou em institutos de pesquisa. Após a conclusão do doutorado, observa-se que cerca de $90 \%$ deles encontram-se em plena atividade profissional, geralmente no setor público e em universidades. São raros os que trabalham em empresas. Mais de $90 \%$ desenvolvem pesquisas em seu trabalho atual.

Os mestres em Bioquímica recebem em média cerca de $\mathrm{R} \$ 2,4$ mil mensais. Os que atuam em IES, na administração pública ou em institutos de pesquisa têm rendimentos médios similares, da ordem de $\mathrm{R} \$ 2,1$ mil, bem menor do que os $\mathrm{R} \$ 3,3$ mil relativos aos que trabalham em empresas. O setor público paga bem menos do que o privado (médias respectivamente de $\mathrm{R} \$ 2,0$ mil e $\mathrm{R} \$ 3,0$ mil). Os doutores em Bioquímica recebem em média cerca de $\mathrm{R} \$ 3,1$ mil mensais. Os que atuam em IES e em institutos de pesquisa têm rendimentos médios muito próximos à média global. Os que recebem mais estão na administração pública e a menor remuneração é paga pelas empresas, cerca de $\mathrm{R} \$ 2,4$ mil, bem inferior ao que percebem os mestres em Bioquímica que trabalham em empresas. Os setores público e privado remuneram de forma similar, com um pequeno diferencial, de cerca de $5 \%$, a favor do primeiro. Os homens são melhor remunerados do que as mulheres: cerca de $15 \%$, entre os doutores, e aproximadamente $30 \%$, no caso dos mestres.

A motivação para a pós-graduação decorre basicamente do desejo de seguir ou aprimorar carreiras de pesquisador ou docente. Mais de $70 \%$ de mestres e doutores indicaram que esses dois quesitos foram muito importantes para a sua escolha pelo mestrado ou pelo doutorado. Esses percentuais são maiores no caso dos doutores. A vontade de seguir carreira de pesquisador contribuiu mais do que a de seguir carreira docente, especialmente entre os doutores. Exerce também forte influência o desejo de ampliar as oportunidades profissionais e de obter um melhor trabalho em termos acadêmicos e profissionais. $\mathrm{Cu}-$ riosamente, considerando as motivações associadas às maiores e melhores oportunidades de trabalho, são poucos os entrevistados que identificaram a possibilidade de obter melhor nível de renda e o incentivo da bolsa de estudos como fatores que pesaram muito para sua opção.

Mestres e doutores em Bioquímica avaliam de forma muito positiva o curso que fizeram, realçando, em especial, a experiência em pesquisa e a formação teórica. $\mathrm{O}$ primeiro quesito foi considerado por quase $80 \%$ dos mestres e por mais de $95 \%$ dos doutores como estando contribuindo muito para o seu exercício profissional. O segundo, recebeu a mesma avaliação de aproximadamente $70 \%$ dos mestres e de cerca de $85 \%$ dos doutores. Foram considerados também muito importantes para o exercício profissional a reciclagem de conhecimentos ( $70 \%$ dos mestres e $80 \%$ dos doutores) e os contatos acadêmicos e profissionais ( $60 \%$ dos mestres e mais de $3 / 4$ dos doutores).
Em todos os quesitos, os doutores fazem uma avaliação ainda mais positiva do curso do que os mestres. Em geral essa avaliação positiva independe do tipo de trabalho atual dos titulados. No entanto, as avaliações menos favoráveis são externadas mais freqüentemente por aqueles que trabalham em empresas, tanto no caso dos mestres quanto dos doutores.

Mestres e doutores, estes mais do que aqueles, também avaliam de forma positiva a contribuição que o curso trouxe para a sua situação profissional. Quase $80 \%$ dos mestres e cerca de $85 \%$ dos doutores consideram que têm hoje melhores oportunidades de trabalho do que antes de se titularem, sendo que metade dos mestres e aproximadamente $2 / 3$ dos doutores julgam que essas oportunidades são hoje muito melhores do que antes do curso. Cerca de $3 / 4$ dos mestres e mais de $85 \%$ dos doutores avaliam que sua renda atual é melhor do que antes de se titularem, sendo que $60 \%$ de ambos os grupos julgam que essa renda é hoje muito melhor do que antes do curso. Aproximadamente $85 \%$ dos mestres e $90 \%$ dos doutores consideram que têm hoje um trabalho melhor, em termos acadêmicos e profissionais, do que antes do curso, sendo que mais de $70 \%$ consideram que nesse aspecto a situação hoje é muito melhor do que antes de se titularem.

Os entrevistados também consideram que o título acarretou-lhes maior participação em eventos e em associações científicas e profissionais, em relação à que tinham anteriormente, ainda que a avaliação desses dois quesitos seja um pouco menos positiva do que a daqueles que foram mencionados no parágrafo anterior. Essa avaliação amplamente favorável do impacto do grau acadêmico pós-graduado nas atividades profissionais é observada para quase todos os tipos de atividades profissionais a que os doutores se encontram vinculados, exceto no caso daqueles que estão trabalhando em empresas, que geralmente avaliam de forma negativa este impacto, especialmente no caso dos doutores.

\section{AGRADECIMENTOS}

Os autores agradecem à CAPES e à UNESCO, pelo apoio financeiro e suporte indispensáveis para a realização do projeto, e aos colegas e amigos J. Velloso, H. Sampaio, M. do C. de L. Peixoto e T. F. Bogutchi, pelas valiosas sugestões e apoio à redação deste texto.

\section{NOTAS E REFERÊNCIAS}

1. Os autores consultaram especialistas sobre as fontes de referência em relação a esse tema. Foram contatados diretamente os seguintes Professores da UFMG: C. A. P. Tavares, ex-coordenador do programa de pós-graduação em Bioquímica e atual Diretor do Instituto de Ciências Biológicas, P. S. L. Beirão, ex-Pró-Reitor de Pesquisa, e T. A. da M. Santos, ex-Reitor. De forma indireta, por meio do Prof. Beirão, foi também consultado o Prof. C. R. Diniz, aposentado pela UFMG, atualmente desenvolvendo pesquisas no Instituto René Rachou, em Belo Horizonte. Esses especialistas indicaram a revista Ciência e Cultura como o periódico que, com maior probabilidade, veicularia esse tipo de "issue". Um levantamento exaustivo em duas décadas desse periódico, de 1980 a 1999, não revelou a existência de sequer um trabalho sobre o tema.

2. Prado, J.L.; Ciência e Cultura 1978, 30, 549.

3. Prado, J.L. Em A História das Ciências no Brasil; Ferri, M.G.; Motoyama, S., orgs.; EDUSP: São Paulo, 1979, vol . I, cap. 5.

4. Brasil; Avaliação da pós-graduação - 1998: síntese dos resultados, CAPES: Brasília, 1999; Brasil; Uma Década de Pós-graduação: 19871996, CAPES: Brasília, 1997; Brasil; Avaliação Internacional da CAPES: relatório do Grupo de Consultores Internacionais, CAPES: Brasília, 1997, http://www.capes.gov.br, acessada em 2001; Brasil; Avaliação da pósgraduação: síntese dos resultados; 1981-1993, CAPES: Brasília, 1996; Brasil; Avaliação da pós-graduação - 1996: síntese dos resultados, CAPES: Brasília, 1996.

5. Martins, T. Em As Ciências no Brasil; Azevedo, F., org.; 2a ed., Ed. UFRJ: Rio de Janeiro, 1994, vol. II, cap. 11.

6. Salzano, F. M. Em A História das Ciências no Brasil; Ferri, M.G., Motoyama, S., orgs.; EUSP: São Paulo, 1979, vol. I, cap. 10. 
7. Hoje, Universidade Federal do Rio de Janeiro.

8. Atualmente, Universidade Federal de Minas Gerais.

9. Hoje, Universidade Federal do Paraná.

10. Schwartzman, S.; Formação da Comunidade Científica no Brasil, Editora Nacional: São Paulo, 1979, caps. 7 e 9.

11. Giesbrecht, E.; Selecta Chimica 1957, 16, 5.

12. Moura Campos, M.; Selecta Chimica 1960, 19, 15.

13. Revista Selecta Chimica, Selecta Química 1965, 24, 61.

14. As primeiras 4 teses de doutorado foram apresentadas em 1942, seguindose uma interrupção até 1945 e, a partir desse ano, a produção tornou-se regular: 15 teses nos anos 40, 9 nos anos 50 e 8 nos anos 60, até 1965. A diminuição da produção de teses possivelmente tenha sido reflexo do falecimento de Rheinboldt.

15. Atualmente Universidade Federal do Estado de São Paulo, UNIFESP.

16. Na Física, são 31 programas e na Química, 37, envolvendo, tanto em uma quanto em outra área, 16 estados da Federação e o Distrito Federal.

17. Convém aqui mencionar que, na avaliação de 98 , enquanto na Bioquímica $25 \%$ dos programas ( 3 em 13) obtiveram conceito 7, na Física e na Química o percentual de programas que obteve esse conceito não chegou a 5\% (respectivamente 1 em 31 e 1 em 37 ).

18. Em relação às áreas de Física e de Química, que eventualmente foram aqui usadas para outras comparações, observa-se que, no período considerado, a área de Bioquímica cresceu bem mais do que a de Física e em proporções similares à verificada na de Química.

19. Esta pesquisa considerou, em seu conjunto, cinco programas de pósgraduação em Bioquímica, que correspondem a cerca de $40 \%$ dos programas de pós-graduação do país nessa área. Desses, um foi classificado como 7, dois, como 6, um, como 5 e um, como 4, na avaliação da CAPES referente ao ano de 1998. Todos esses cinco programas começaram a funcionar até 1970, já tendo, portanto, completado 30 anos de atividade.

20. Velloso, J., org.; A pós-graduação no Brasil: formação e trabalho de mestres e doutores no país, v. I: Administração, Agronomia, Bioquímica, Clínica Médica, Engenharia Civil, Engenharia Elétrica, Física, Química e Sociologia, CAPES/UNESCO: Brasília, 2002.

21. O projeto foi coordenado pelo Professor Jacques Velloso, da UnB.

22. Foi usado o pacote estatístico conhecido pela sigla SPSS.

23. No caso dos mestres, $36 \%$ dos entrevistados foram titulados pela UFRJ, $25 \%$, pela UFRGS, $15 \%$, pela UFMG, $14 \%$, pela USP e $10 \%$, pela UFPE. Entre os doutores, $35 \%$ dos entrevistados foram titulados pela USP, $30 \%$, pela UFMG, $18 \%$, pela UFRGS e17\%, pela UFRJ.

24. Talvez seja coincidência, mas convém registrar que na área de Química é também na UFRJ que se verifica maior proporção de titulados advindos de áreas conexas da graduação.

25. O presente estudo coletou um grande número de dados, muitos dos quais não foram registrados em tabelas ou gráficos, evitando-se dessa forma alongar o texto em demasia. No entanto, algumas vezes iremos fazer uso dessas apurações complementares, para melhor apresentar os resultados da pesquisa. É o que ocorreu nesse parágrafo.

26. Para os graduados em 1985, a idade média de graduação foi inferior a 23 anos, passando para 23 anos e meio, entre 1986 e 1990, para 24 anos, no período 1990/1993 e para 25 anos, entre 1994 e 1996.

27. Quase $90 \%$ dos doutores graduaram-se até o final dos anos 80; mais de $50 \%$ dos mestres graduaram-se após 1990

28. Cita-se o exemplo do curso de Química da UFMG, para o qual uma reforma curricular implantada em 1985 resultou em crescimento expressivo das taxas de evasão e em aumento de cerca de $15 \%$ a $20 \%$ na duração média do curso.

29. O banco de dados inclui apenas dois casos da coorte que se formou em 1990 e dez que se formaram em 1991, sendo que, entre estes últimos, um ingressou no mestrado 18 anos após concluir a graduação e outros três, mais de dez anos depois de se graduarem. Estes fatos explicariam a grande diferença observada na variável "tempo entre a graduação e o início do mestrado", para estas duas coortes, em relação ao restante da série. Já o pequeno número de casos destas duas coortes explica-se pelo fato de a grande maioria dos mestres em Bioquímica titulados nestes dois anos já ter concluído o seu doutorado. Foram, portanto, entrevistados como doutores e não como mestres.

30. Foram 100 entrevistas, para as coortes de 1990 a 1995 e 160 , para as coortes de 1996 a 1998. Até onde foi possível apurar com os dados colhidos na pesquisa, dois são os principais fatores que concorrem para a diferença de população desses dois conjuntos de coortes. O primeiro deles, e que mais contribui para o resultado, é o substancial aumento no número de titulados por ano, a partir sobretudo de 1996. O segundo, é que parte expressiva dos mestres titulados nos anos iniciais da década já se doutorou e, portanto, foi entrevistada como doutor e não como mestre. Considerando que esses mestres, em princípio de melhor desempenho acadêmico, possam ter procurado a pós-graduação mais rapidamente do que os demais, a diminuição do interregno entre a conclusão da graduação e o início da pós poderia estar associado a esse fator e não representar uma tendência. Em uma primeira aproximação, poder-se-ia dizer que o primeiro fator contribui para $60 \%$ da diferença e o segundo, para $40 \%$ dela.

31. Registrou-se o ano de fim da graduação e de início da pós e, por subtração, calculou-se o interregno entre os dois eventos. Sendo assim, para aqueles que concluíram a graduação em dezembro de um ano e ingressaram na pós em março do ano subseqüente, o tempo registrado, correspondente a esse interregno, foi de 1 ano. Procedimento similar foi utilizado em todos os cálculos relativos ao tempo decorrido entre dois eventos quaisquer.

32. Há também uma diferença expressiva nas populações desses dois conjuntos de coortes, respectivamente, 80 e 131. Mas, aqui, ao contrário do caso dos mestres, todos os titulados foram procurados para as entrevistas, independentemente de seus estudos posteriores ao doutorado. Ou seja, a diferença de população deve-se exclusivamente ao aumento do número de titulados, não podendo se imaginar diferenças de desempenho acadêmico desses dois conjuntos de coortes, em razão de sua diferença de população.

33. Mangematin, V.; Research Policy 2000, 29, 741; Velloso, J.; Velho, L.; Mestrandos e doutorandos no país: trajetórias de formação, CAPES: Brasília, 2001

34. Ver nota 31.

35. Sampaio, H.; Limongi, F.; Torres, H.; Equidade e Heterogeneidade no Ensino Superior Brasileiro, INEP: Brasília, 2000.

36. Estudo realizado por Braga e colaboradores, referente ao curso de Química da UFMG, revela que os graduados que se dirigem para a pós-graduação apresentam, em média, desempenho acadêmico na graduação superior ao dos demais colegas (ver Revista da Rede de Avaliação Institucional da Educação Superior 1999, 4, 67).

37. Mesmo levando-se em conta o mencionado na nota 29 e excluindo-se da análise as coortes de 90 e 91, ainda assim, a tendência de diminuição acentuada na duração do mestrado é nítida.

38. Uma dessas hipóteses seria a de que a maior dedicação e maturidade dos filhos de pais com menor nível de instrução, advindas de uma maior necessidade de concluírem o curso rapidamente, compensariam o menor preparo que teriam, para prosseguir seus estudos.

39. O menor valor ocorre na UFMG, 4,4 anos, e o maior na UFRGS, 4,7 anos.

40. A duração do curso é em média 4,1 anos para os que foram diretamente para o doutorado e 4,7 anos para os demais.

41. Ver nota 29

42. Os valores encontrados foram, em anos: USP, 28,0, UFRJ, 29,0, UFMG, 29,3, UFRGS, 31,5 e UFPE, 32,2.

43. Convém aqui observar a organização peculiar dos estudos de pós-graduação na Itália, que pode ser verificada em Eco, H.; Como se faz uma tese, Editora Perspectiva: São Paulo, 1999.

44. A situação se agrava ainda mais, porque a idade de titulação dos que vão diretamente da graduação para o doutorado parece estar aumentando. Ela foi de 29,1 anos, para as coortes de 90 a 94, passando a ser de 32,6 anos, para as coortes de 1995 a 1998 .

45. Neste trabalho foram classificados como pertencentes à academia os profissionais vinculados ao ensino superior e aos institutos de pesquisa.

46. Nesta pesquisa foram entrevistados 259 mestres titulados nos anos 90, sendo que 131 deles estão cursando o doutorado. Entre os doutores entrevistados, 73 concluíram anteriormente o mestrado, também na década de 90. Portanto, o universo de mestres titulados nas instituições pesquisadas nos anos 90 foi de 332, sendo que 204 deles, que correspondem a $61 \%$ do total, já se doutoraram ou estão se doutorando. É possível ainda supor que outros mestres, titulados mais recentemente, ainda irão se vincular a programas de doutorado. Finalmente, os mestres que se encontram residindo no exterior, informação que foi obtida na pesquisa, mas ainda não registrada no banco de dados, em boa parte estão fazendo doutorado.

47. Na realidade, mais de $40 \%$ daqueles que não tinham atividade profissional quando da inscrição, passaram a tê-la, com a conclusão do mestrado. No entanto, é preciso abater deste percentual aqueles que relataram atividade profissional antes de ingressarem no mestrado e que agora não a têm.

48. Como visto, no caso dos mestres essa opção é mais freqüente, se relacionando quase que exclusivamente ao prosseguimento dos estudos em nível de doutorado. Mas existem também os doutores que, logo em seguida à sua titulação, voltam à universidade, para estágios de pós-doutorado.

49. Supõe-se aqui que os mestres inativos que ainda não são estudantes de doutorado, como não estão procurando emprego, aguardam apenas uma oportunidade para se vincularem a cursos de doutorado. Hipótese reforçada pelo fato de mais de $80 \%$ deles terem se titulado nos dois últimos anos da coleta de dados, ou seja, em 1997 ou em 1998.

50. Como visto, mais de $80 \%$ dos mestres hoje inativos irão concluir também o doutorado e $90 \%$ dos doutores atuam na área acadêmica.

51. Os atualmente inativos correspondem aos seguintes percentuais: UFRJ, $15 \%$; USP, $11 \%$; UFMG, $5 \%$ e UFRGS, $3 \%$. 
52. Este fato explica em parte a concentração dos atuais inativos entre os que se titularam no período 96/98.

53. Para a análise desse parágrafo, somaram-se os percentuais referentes às categorias de empregado do setor privado, autônoma/consultor e proprietário.

54. Como vimos, entre aqueles que se formaram na USP e na UFRGS é maior a fração dos que se encontram vinculados a empresas. Mas este fator isoladamente não explica todas as diferenças de remuneração observadas. Se apenas ele fosse levado em conta, seria obtida uma remuneração $20 \%$ maior do que a efetivamente verificada, no caso dos titulados pela UFMG e $20 \%$ menor, para os que se formaram na USP.

55. Como vimos, entre aqueles que se formaram na USP e na UFRGS é maior a fração dos que se encontram vinculados a empresas. Mas este fator isoladamente não explica todas as diferenças de remuneração observadas. Se apenas ele fosse levado em conta, seria obtida uma remuneração $20 \%$ maior do que a efetivamente verificada, no caso dos titulados pela UFMG e $20 \%$ menor, para os que se formaram na USP.

56. Convém registrar que apenas 7 doutores, correspondendo a $3 \%$ do universo entrevistado, trabalham em empresas. No caso dos mestres, 27, que correspondem a $10 \%$ dos entrevistados, trabalham em empresas. Essa comparação reforça a afirmativa.

57. No que se refere à importância das relações pessoais na sociedade brasileira, ver Matta, R. Carnavais, Malandros e Heróis, 4ª ed.; Zahar Editores: Rio de Janeiro, 1983.

58. Por exemplo, embora tendo tempo de titulação comparável ao dos homens, as mulheres podem ter menor tempo de serviço do que os homens. Ou ocuparem, em menor proporção, cargos de chefia. Ou, as mulheres têm ganho menor na prestação de serviços da instituições públicas de ensino superior. Ou, ainda, as mulheres tendem a subestimar sua renda e os homens, a superestimá-la.

59. Aqueles que são docentes do ensino superior aparecem no gráfico sob a classificação "universidade". Isso ocorre porque a grande maioria dos que são docentes do ensino superior atuam em instituições universitárias: $90 \%$ no caso dos mestres e $94 \%$, no caso dos doutores.

60. Ainda assim, $85 \%$ dos raros doutores que estão trabalhando em empresas consideraram a experiência em pesquisa como tendo contribuído muito para a sua formação.

61. No conjunto dos entrevistados, cerca de $90 \%$ declararam que desenvolvem pesquisas em seu trabalho atual. No entanto, entre aqueles que hoje trabalham em empresas a percentagem correspondente é cerca de $40 \%$.

62. Deve-se ressaltar que estão computadas apenas as respostas dos que declararam vínculo profissional atual, quer estejam em plena atividade ou afastados. Isso corresponde a quase $50 \%$ dos mestres e a mais de $90 \%$ dos doutores.

63. Note-se que apenas $1 / 3$ dos mestres trabalhava quando se inscreveu para o curso e que atualmente metade deles trabalha (a outra metade, aproximadamente, segue doutorado). Assim, as informações da Figura 6a correspondem à comparação que: (i) uma parte dos mestres faz entre o trabalho que antes desenvolviam e o trabalho atual; (ii) outra parte faz entre o que percebiam ser o trabalho que poderiam antes desenvolver e suas atuais atividades.

64. Aplica-se aos doutores raciocínio similar ao feito para os mestres na nota anterior. Cerca de $1 / 3$ dos doutores tinha vínculo profissional quando ingressaram no curso, enquanto que atualmente quase $90 \%$ encontram-se nessa situação. 